University of South Florida

DIGITAL COMMONS

Digital Commons @ University of

@ UNIVERSITY OF SOUTH FLORIDA

South Florida

All publications

USF Libraries Florida COVID-19 Research

Collections

$1-1-2020$

\title{
Faith in Trump, Moral Foundations, and Social Distancing \\ Defiance during the Coronavirus Pandemic
}

\author{
Amanda Graham \\ Georgia Southern University \\ Francis T. Cullen \\ University of Cincinnati \\ Justin T. Pickett \\ University at Albany \\ Cheryl Lero Jonson \\ Xavier University \\ Murat Haner \\ University of South Florida, hanerm@usf.edu
}

See next page for additional authors

Follow this and additional works at: https://digitalcommons.usf.edu/usf_fcrc_all

Part of the Medicine and Health Sciences Commons

\section{Scholar Commons Citation}

Graham, Amanda; Cullen, Francis T.; Pickett, Justin T.; Lero Jonson, Cheryl; Haner, Murat; and Sloan, Melissa M., "Faith in Trump, Moral Foundations, and Social Distancing Defiance during the Coronavirus Pandemic" (2020). All publications. 11.

https://digitalcommons.usf.edu/usf_fcrc_all/11

This Article is brought to you for free and open access by the USF Libraries Florida COVID-19 Research Collections at Digital Commons @ University of South Florida. It has been accepted for inclusion in All publications by an authorized administrator of Digital Commons @ University of South Florida. For more information, please contact digitalcommons@usf.edu. 


\section{Authors}

Amanda Graham, Francis T. Cullen, Justin T. Pickett, Cheryl Lero Jonson, Murat Haner, and Melissa M. Sloan 


\title{
Faith in Trump, Moral Foundations, and Social Distancing Defiance during the Coronavirus Pandemic
}

Socius: Sociological Research for a Dynamic World Volume 6: I-23

(C) The Author(s) 2020 Article reuse guidelines: sagepub.com/journals-permissions DOI: 10.1 | $77 / 2378023$ |209568| 5 srd.sagepub.com

(S)AGE

\author{
Amanda Graham '(D), Francis T. Cullen², Justin T. Pickett ${ }^{3}$, \\ Cheryl Lero Jonson ${ }^{4}$, Murat Haner ${ }^{5}$, and Melissa M. Sloan ${ }^{5}$ (D)
}

\begin{abstract}
Purpose: Over the past several months, the coronavirus has infected more than six million Americans and killed nearly 200,000. Governors have issued stay-at-home orders, and prosecutors have filed criminal charges against individuals for defying those orders. And yet many Americans have still refused to keep their distance from their fellow citizens, even if they had symptoms of infection. The authors explore the underlying causes for those who intend to defy these norms.

Methods: Using national-level data from a March 2020 survey of 989 Americans, the authors explore intentions to defy social distancing norms by testing an interactionist theory of foundation-based moral behavior in combination with faith in President Trump during the coronavirus pandemic. The analysis controls for a range of variables, including measures of low self-control and deterrence.

Results: Low self-control is the strongest predictor of defiance intentions. Consistent with interactionist theory, defiance intentions are significantly higher for those holding specific faith in Trump and those endorsing binding foundations. Furthermore, the interaction of these two variables is significant and in the predicted direction. The results hold for two different measures of faith in Trump.

Conclusions: Even with a strong effect for low self-control, faith in President Trump is a strong predictor of refusal to social-distance, and its effect is largest among individuals high in binding foundations.
\end{abstract}

\section{Keywords}

COVID-19, social distancing, President Trump, moral foundations, pandemic

First appearing in the United States on January 21, 2020, in Snohomish County, Washington, coronavirus disease 2019 (COVID-19) has drastically changed the lives of Americans (The New York Times 2020). Once seen only in Hollywood pandemic movies, the concepts of "social distancing," "self-isolation," and "quarantining" have now become part of Americans' everyday experience. Using national-level survey data collected on March 28 and 29, 67 days after the United States' first known infection and 28 days after its first death, we focus on defiance of social distancing directives.

\footnotetext{
${ }^{1}$ Various criminological theories use the term defiance to refer to different constructs (e.g., Sherman 1993; Tittle 1995). In the current article, we define it simply as the refusal to follow formal (governors') or informal (health professionals') directives to social-distance.
}

At the time of our survey, officials reported 123,653 coronavirus cases and 2,135 deaths in the United States (The New York Times 2020). In response, governors in 26 states had issued mandatory stay-at-home orders, and advisory warnings to practice social distancing had become near universal (Mervosh, Lu, and Swales 2020). In several instances, criminal charges were filed against those who exposed others to their oral fluids (e.g., licked products at a store, coughed on

\footnotetext{
'Georgia Southern University, Statesboro, GA, USA

'University of Cincinnati, Cincinnati, OH, USA

${ }^{3}$ University at Albany, Albany, NY, USA

${ }^{4}$ Xavier University, Cincinnati, OH, USA

${ }^{5}$ University of South Florida, Tampa, FL, USA

\section{Corresponding Author:}

Amanda Graham, Georgia Southern University, School of Criminal Justice and Criminology, P.O. Box 8I05, Statesboro, GA 30460, USA.

Email: akgraham@georgiasouthern.edu
} 
an officer) or held large gatherings such as parties or church services (Burke 2020a, 2020b; Koop 2020; Peel 2020; Winton and Fry 2020). Prosecutors in New Jersey, for example, had by the end of March filed charges against more than 20 people for defying social distancing directives (Dean and Rushing 2020).

The news of the threat posed by COVID-19 was unavoidable: the public was paying attention. Indeed, in our sample, only 4 percent of respondents stated that they were following the news on the coronavirus crisis "not too closely," and the percentage of those answering "not closely at all" was but 0.4 percent. By contrast, 95.7 percent answered that they were following this news either "very closely" (66.6 percent) or "fairly closely" (35.1 percent). In this context, an important issue arises: would Americans be willing to endanger others and themselves by ignoring emergent social distancing norms, and if so, why? This project, conducted as the coronavirus crisis was gaining force, was designed to address this matter.

Criminological theories are useful for explaining deviant behavior, whether illegal or legal (see, e.g., Cullen, Latessa, and Jonson 2012; Gottfredson and Hirschi 1990). Three approaches, which the data allow us to test, seem particularly relevant. First, Gottfredson and Hirschi's (1990) general theory of crime would predict that those with low self-control would violate social distancing norms, because of a desire for immediate gratification, a preference for risk, and a lack of concern for consequences. Empirical support for this perspective is consistent (Pratt and Cullen 2000; Vazsonyi, Mikuška, and Kelley 2017). Second, rational choice/deterrence theory highlights the salience of perceived costs and fear (Paternoster 2018; Paternoster and Bachman 2013; Pickett et al. 2018). In the current context, compliance with social distancing norms should be greater among those who perceive a higher certainty of death and who are afraid of being infected and harmed. Third, Agnew's (2014) social concern theory argues that crime will be less likely among people who "give more consideration to others than to their own interests" (p. 5). Altruistic fear embodies this concern for others' welfare and should encourage social distancing, as a defensive or precautionary behavior that helps guard others from infection (see Drakulich 2015; Warr and Ellison 2000).

Social distancing in the United States, however, is enmeshed in a moral-political context. In most other societies (President Jair Bolsonaro in Brazil is a notable exception), national leaders, such as Queen Elizabeth II of the United Kingdom and German chancellor Angela Merkel, are preaching communitarian values and adherence to safe social practices (Brewington 2020; Rising and Moulson 2020). Their influence, if any, would be to increase social distancing. This effect might well be the opposite in the United States, where President Trump has dominated public discourse surrounding the coronavirus crisis. Although evolving, his messaging has been to downplay the risks of the outbreak and to accuse Democrats of using the crisis as a means (calling it "their hoax"; February 28) to undermine him (Rupar 2020a), even after his administration instituted a travel ban for foreign nationals traveling from China a month earlier (January 31) and the World Health Organization declared the virus to be an outbreak (January 30); the following day, February 29, the Trump administration instituted further travel restrictions (Taylor 2020). Charismatic and connected to the public through social media, it is possible that people who have "faith in Trump" would be less likely to comply with social distancing norms.

Moreover, in The Righteous Mind Haidt (2012) argued persuasively that politics cannot be reduced to partisanship but rests on a foundation of moral intuitions. Although making inroads into criminology (Pereira 2017; Silver and Abell 2016; Silver and Silver 2017), Haidt's moral foundation theory (MFT) has not been used extensively to explain offending. The decision to socially distance is a moral decision for two reasons. First, it involves weighing individual preferences against the possibility of spreading harm to others. Second, given the political context, it involves weighing the moral importance of signals from authority-from the president himself, governors, and public health officials - about group interests and cohesion. Haidt's framework thus has implications for individual choice as well as for the effects of allegiance to authority figures, such as President Trump.

As this discussion suggests, in the present project our research strategy is to examine behavioral intentions to offend - to engage in conduct that violates norms of social distancing (e.g., disobeying the governor's order to stay at home, socializing with friends, holding planned social events, not avoiding close contact, and going out in public with symptoms). Beyond a range of sociodemographic controls, we examines the impact of self-control, perceived certainty of death, personal fear, and social concern, anticipating that defiance intentions would be increased by low self-control and decreased by measures of deterrence and concern. Most important, the study is focused on whether faith in President Donald Trump - in general or in relation to the coronavirus crisis specifically - and certain moral intuitions interact to reduce compliance with social distancing norms. As will be shown, such effects occur, indicating the potential importance of considering moral-political factors in criminological inquiries.

\section{President Trump's Moral Influence}

\section{Why There Is an Influence}

Three possible reasons exist as to why President Trump might influence the public's social distancing behavior. First, Trump's potential to sway public opinion and behavior is not unique to him. In fact, previous research finds that presidents have the capacity to influence public views because their role is that of the lead policy maker and representative of the country (see, e.g., Cohen 1995, 1997; Cohen and Hamman 2003; Lawrence 2004; Shi, Lu, and Pickett 2020). As such, the president's words carry weight as a means of shaping public 
opinion (Druckman and Jacobs 2009; Hawdon 2001; Tulis 1987). For example, in Cohen's (1995) longitudinal study of the impact of presidents' State of the Union addresses, he found that the policy issues mentioned in the addresses see subsequent increases in public concern with those policies. Studies have also found that presidential statements affect crime attitudes and perceptions among both Democrats and Republicans (Ramirez 2013; Shi et al. 2020). Likewise, in his analysis of the communitarian, individualistic, and rehabilitative presidential rhetoric surrounding the "war on drugs" between 1984 and 1992, Hawdon (2001) argued that Reagan "masterfully incited the public and helped create a moral panic. The use of communitarian arguments rallied support for an aggressive war on drugs" (p. 438).

Second, and relatedly, President Trump has endeavored to transform the role of the presidency into his being, as he has been termed, America's first "influencer in chief" (Donovan 2019). As a former reality television star, he is viewed by many as charismatic (P. Jackson 2019; Khazan 2016; Post and Doucette 2019), a characteristic that, in combination with the impact of social media, he uses to speak to his supporters. For example, despite his lawyers' and advisers' advice to curb the use of tweets, as president, Trump has tweeted more than 14,000 times (an average of more than 14 times per day) to his 75.8 million followers (Baker and Thrush 2017; Trump 2020a; Trump Twitter Archive 2020). As an avowed social media president, he has nearly unfettered access to communicate with the public in a way that previous presidents have not. Additionally, much like any other social media influencer, President Trump is obsessed with his ratings (Lowry 2017; Rubin 2020). For example, consider his March 29 tweet: "Since reviving the daily White House briefing Mr. Trump and his coronavirus updates have attracted an average audience of 8.5 million on cable news, roughly the viewership of the season finale of 'The Bachelor.' Numbers continue to rise" (Trump 2020c). Similarly, he is highly concerned with his polling numbers as indicators of success as an "influencer," claiming, for instance, that his "Gallup Poll numbers on the handling of this situation are outstanding, the best" (Lowry 2017; Rubin 2020; Trump 2020b).

Furthermore, as the "influencer in chief," early research points to his capacity to shape the minds and behaviors of Americans, for better or for worse. For example, in a 2017 survey of blacks in America, respondents' worries about being arrested, imprisoned, and brutalized by the police increased as a result of President Trump's election and his "war on crime" rhetoric (McManus et al. 2019). Additionally, he has been used as the "inspiration" for violence against immigrants (Schanzer 2019), black Americans (Harper 2019; KOMO Staff 2016), Trump critics (Swaine and Adolphe 2019), and LGTBQ+ Americans (Filosa 2017). Likewise, researchers have found correlations between the timing of Trump statements and influxes in Federal Bureau of Investigation-reported hate crimes (Levin and Nakashima 2019), including the recent verbal and physical victimization of Asian Americans in the context of the "China virus" accusation (Johnson 2020; Tavernise and Oppel 2020). Thus, his ardent supporters seem to be heeding his message and placing it into action, even when doing so involves breaking laws; indeed, President Trump has sometimes promised pardons for lawbreakers who follow his directives (Graham 2019).

A final example of President Trump's sizable influence is Republicans' views on political issues. As Hale and Kamenchuk (2020) noted, "Trump has successfully converted many of his party's rank and file to his views on issues from free trade to the abandonment of bedrock ideological principles ... this also includes their views on Russia and Putin." Their polling revealed that 6 in 10 Republicans see Putin as a "good leader for Russia," a figure that climbs to 68 percent in red states. These results are stunning given the GOP's longstanding hostility to Russia and the reality that "not long ago, association with anyone in the Kremlin was politically damaging in the United States" (Hale and Kamenchuk 2020).

Third, President Trump's messaging may also hold unique influence because of the reinforcement of his messages by news networks, such as Fox News, and by conservative talk radio hosts, such as Rush Limbaugh, who also achieve strong levels of viewership. For example, Fox News holds the top ratings position for networks, averaging 3.5 million primetime viewers daily (Wulfsohn 2020). Similarly, as the most-listened-to radio program in the United States, Rush Limbaugh's show bends the ears of more than 25 million listeners each month (Forbes 2020). But it is not only their viewership and the hosts' commentaries that pass along his influential messages; President Trump himself often appears on or calls into these networks (e.g., DePaolo 2020; Hains 2019) and consults with the hosts about presidential decisions. For example, at Trump's Mar-aLago estate, he met with Fox News host Tucker Carlson to discuss coronavirus policies, with Carlson attempting to stress the seriousness of this virus to the president (Sullivan 2020).

\section{What the Influence Is}

Beyond the magnitude of President Trump's influence, the question arises as to how his messaging has affected the direction of public views on the coronavirus and the need to social-distance. Under normal circumstances, virtually any U.S. president regardless of party would have conveyed a consistent message supporting the seriousness of the outbreak and the risks to public health it posed (see, e.g., Bush 2003; Mosk 2020; Obama 2014). Their effect likely would have been to increase the public's willingness to engage in social distancing. With President Trump, however, the messaging, and thus potential effect, are in the opposite direction.

Starting with his initial statements about the virus, numerous observers have documented that President Trump downplayed the seriousness of this pandemic (Cillizza 2020; Evon 2020; Leonhardt 2020; Lipton et al. 2020; Paz 2020; Qiu 2020; Rupar 2020b). For example, on January 22, 2020, the day after the first case in the United States was identified, Trump asserted, "We have it totally under control. It's one 
Table I. Selected Quotes by Supporters of President Donald Trump.

\begin{tabular}{|c|c|c|}
\hline Date & Source & Quote \\
\hline \multicolumn{3}{|l|}{ Fox News } \\
\hline $02-27-20$ & Sean Hannity & $\begin{array}{l}\text { Tonight, I can report the sky is absolutely falling. We are all doomed. The end is near. The apocalypse } \\
\text { is imminent and you going to all die. Or, at least, that is what the media mob would like you to think. }\end{array}$ \\
\hline $02-27-20$ & Sean Hannity & Zero people in the United States of America have died from the coronavirus. Zero. \\
\hline $02-28-20$ & Geraldo Rivera & $\begin{array}{l}\text { The far more deadly, more lethal threat right now is not the coronavirus. It's the, it's the ordinary } \\
\text { old flu. People are right now. Nobody has died yet in the United States as far as we know from this } \\
\text { disease. }\end{array}$ \\
\hline $03-02-20$ & Dr. Drew Pinsky & It's milder than we thought. The fatality rate is going to drop. \\
\hline $03-03-20$ & Jesse Watters & $\begin{array}{l}\text { You want to know how I really feel about the coronavirus, Juan. If I get it, l'll beat it. I AM NOT } \\
\text { AFRAID OF THE CORONAVIRUS and no one else should be that afraid either. }\end{array}$ \\
\hline 03-06-20 & Dr. Marc Siegel & This virus should be compared to the flu, cuz at worst, at worst, worst case scenario, it be the flu. \\
\hline 03-07-20 & Jeanine Pirro & It's a virus, like the flu. All the talk about coronavirus being so much more deadly doesn't reflect reality. \\
\hline $03-08-20$ & Pete Hegseth & $\begin{array}{l}\text { This is one of those case where the more I learn about coronavirus, the less concerned I am. There's } \\
\text { of hyperbole. }\end{array}$ \\
\hline 03-09-20 & Lou Dobbs & The national left-wing media playing up fears of the coronavirus \\
\hline 03-09-20 & Laura Ingraham & And the facts are actually pretty reassuring, but you'd never know it watching all this stuff. \\
\hline $03-10-20$ & Ed Henry & When you hear the context, it's not quite as scary. \\
\hline $03-10-20$ & Tomi Lahren & $\begin{array}{l}\text { The sky is falling because we have a few dozen cases of coronavirus on a cruise ship. I am far more } \\
\text { concerned with stepping on a used heroin needle than I am of getting the coronavirus. But, maybe } \\
\text { that's just me. }\end{array}$ \\
\hline $03-1 \mid-20$ & Matt Schlapp & It is very, very difficult to contract this virus. \\
\hline $03-13-20$ & Ainsley Earhardt & $\begin{array}{l}\text { It's actually the safest time to fly. Everyone I know that's flying right now, terminals are pretty much } \\
\text { dead. And then the planes, remember back in the day when you had a seat next to you possibly } \\
\text { empty. You could stretch out a little more. It's like that on every flight now. }\end{array}$ \\
\hline 03-18-20 & Sean Hannity & By the way, this program has always taken the coronavirus seriously. \\
\hline \multicolumn{3}{|c|}{ Other conservative media } \\
\hline $02-24-20$ & Rush Limbaugh & $\begin{array}{l}\text { Yeah, dead right on is the coronavirus is the common cold, folks. The hype of this thing as a pandemic, } \\
\text { as the Andromeda Strain, as oh my God if you get it you're dead. }\end{array}$ \\
\hline \multicolumn{3}{|c|}{ Trump administration } \\
\hline $02-25-20$ & Larry Kudlow & We have contained this. We have contained this. I won't say airtight, but pretty close to airtight. \\
\hline $03-06-20$ & $\begin{array}{l}\text { Kellyanne } \\
\text { Conway }\end{array}$ & It is being contained. And . . . do you not think it's being contained? \\
\hline $03-10-20$ & Mike Pence & $\begin{array}{l}\text { In our line of work, you shake hands. I expect, uh, the President will continue to do that. I'll continue } \\
\text { to do it. }\end{array}$ \\
\hline \multicolumn{3}{|l|}{ Congress } \\
\hline 03-04-20 & $\begin{array}{l}\text { Report on Matt } \\
\text { Gaetz }\end{array}$ & $\begin{array}{l}\text { Republican Matt Gaetz mocked concerns about the spread of the virus by wearing a gasmask on } \\
\text { Capitol Hill. }\end{array}$ \\
\hline $03-11-20$ & $\begin{array}{l}\text { Report on James } \\
\text { Inhofe }\end{array}$ & $\begin{array}{l}\text { When a reporter in the Capitol asked Senator James Inhofe of Oklahoma, 85, what precautions he was } \\
\text { taking, he extended his armed with confidence, "Wanna shake hands?" }\end{array}$ \\
\hline $03-15-20$ & Devin Nunes & $\begin{array}{l}\text { One of thing you can do, if you're healthy, ah, you and your family, it's a great to just go out, go to a } \\
\text { local restaurant. Likely you can get in easily. }\end{array}$ \\
\hline \multicolumn{3}{|c|}{ Elected officials } \\
\hline 03-23-20 & Tate Reeves & Mississippi's never going to be China. Mississippi's never going to be North Korea. \\
\hline
\end{tabular}

person coming in from China, and we have it under control. It's going to be just fine" (Cillizza 2020). The day before, he referred to it as "their new hoax," referencing his Democratic rivals (Rupar 2020a). Likewise, he labeled COVID-19 as the "China virus" (March 18; Vazquez and Klein 2020) and stated it was "like a flu" (February 26). He proclaimed that the coronavirus would "disappear one day ... like a miracle" (February 27) and that the United States has "tremendous control of" the virus (March 15) (Cillizza 2020). As the infected and death tolls mounted and the economy dramatically declined, Trump (2020d) tweeted, "WE CANNOT LET THE CURE BE WORSE THAN THE PROBLEM ITSELF," alluding to the desire to protect the economy at the expense of American lives. He went even further on March 24 to say that he wanted to have "packed churches all over our country" shortly thereafter on April 12 for Easter (Breuninger 2020). These messages all downplayed the need for social distancing as well as the seriousness of the virus itself. President Trump has also publicly contradicted scientific and medical authorities who have recommended additional actions, such as mandating 
masks, to reduce the spread of COVID-19 and spoken about the pandemic's seriousness (Yong 2020).

Trump was not alone, however, in spreading these messages diminishing the threat posed by the coronavirus (see Table 1 for quotations from selected supporters of President Trump). They were reinforced by conservative leaders, such as Devin Nunes of California (Behrmann 2020), who voiced that "it's a great time to just go out, go to a local restaurant" and to "Go to your local pub," and Jerry Falwell, Jr., of Liberty University (Williamson 2020), who felt it was "irresponsible for so many universities to just say 'closed, you can't come back,' push the problem off on other communities and sit there in their ivory towers." Likewise, the vast majority of Republican governors (Brownstein 2020b) supported these messages, with some saying "we must get back to work before our nation totally collapses" (LeBlanc 2020) and that they refuse to use "dictator models like China" to constrict public movement as a means of controlling the virus (Pettus 2020).

On Fox News, just days before our survey, Texas's lieutenant governor suggested that loyal Americans should be willing to die for the U.S. economy (Rodriguez 2020). Another Republican congressman echoed that message, calling for the reopening of the country, even if it kills Americans; he argued doing so would be "the lesser of these two evils" (Levin 2020). Other Trump allies have suggested "socialdistancing rules are a government attack on Christianity" (Lurie 2020:1). President Trump's acting director of the Office of National Intelligence went even further. He put a photo of the Bill of Rights on social media and told his followers: "Signed Permission Slip to Leave Your House" (Sommer, Branco, and Stein 2020).

As these messages reverberated through the conservative echo chamber, megachurches and churches alike insisted on holding services (Murdock 2020), many states won by Trump in 2016 declined to impose shelter orders (Ortiz 2020), several red-state governors have pushed back against their blue cities' calls for aggressive social distancing measures (Brownstein 2020a), and Falwell's Liberty University boldly reopened (Williamson 2020). In this context, faith in President Trump generally and in his views on the coronavirus specifically would be anticipated to foster defiance of social distancing norms.

\section{Who Should Be Influenced Most?}

Two facts about the relationship between politics and morality are now clear. The first is that it is strong (Haidt 2012; Hatemi, Crabtree, and Smith 2019). "Ideological commitments are moral commitments," Graham, Haidt, and Nosek (2009:1029) explained. The second is that it involves moral concerns about more than just protecting individuals. "When morality is equated with the protection of individuals, the central concerns of conservatives ... fall outside the moral domain" (Graham et al. 2009:1030). Specifically, conservatives are morally inclined to give equal, and sometimes greater, weight to group-related concerns, such as threats to their social group's cohesion, to its traditions, or to the authority of its leaders, than to individual-level concerns, such as treating people fairly (Haidt and Graham 2009). Consequently, conservatives tend to be more willing than liberals to support policies that may adversely affect individuals, provided that they believe those policies help maintain the strength of social groups and institutions (Haidt and Graham 2009).

MFT expands the moral domain beyond individual protection, clarifies its connection to ideology, and explains its influence on decision making (Haidt 2012). According to MFT, evolution has given humans "first draft" moral intuitions, which yield intuitive solutions to problems that were common in our ancestors' social environments (Graham et al. 2009:1031). As the brain is to learning, these intuitions are to moral socialization: they provide "innate but modifiable" foundations (Graham et al. 2009:1030). There are five foundations: harm/care, fairness/reciprocity, ingroup/loyalty, authority/respect, and purity/sanctity. And each influences intuitive reactions to a specific type of behavior (Silver 2017). All five are inborn in everyone, but differences in cultural and political socialization cause some foundations to develop more than others, resulting in different "moral cuisines" (Haidt, Graham, and Joseph 2009:110). The moral cuisines of liberals and conservatives in the United States differ primarily on the last three foundations (Graham et al. 2009), which explains much of the political divide in attitudes and behavior (Haidt 2012; Silver and Silver 2017). Specifically, ingroup/loyalty, authority/ respect, and purity/sanctity are far more important morally to conservatives than to liberals (Graham et al. 2009).

Because the individual is the moral unit for the first two foundations, harm/care and fairness/reciprocity, they are "individualizing foundations" (Graham et al. 2009). They emphasize the importance of protecting individuals, are associated with empathy and compassion, and promote altruism and prosocial behavior (Clark et al. 2017). In contrast, the last three foundations, ingroup/loyalty, authority/respect, and purity/ sanctity, are "binding foundations"; their moral unit is the social group, and they emphasize the importance of self-sacrifice, obedience, duty, protecting cultural boundaries, and vigilance for traitors (Graham et al. 2009). The binding foundations bind "individuals into roles and duties in order to create tightly ordered communities" (Milesi and Alberica 2018:238). They are the foundations that underpin collective action in conservative social movements (Milesi and Alberica 2018). ${ }^{2}$

MFT is germane for understanding responses to the COVID-19 pandemic for many reasons. One is that moral foundations influence deviance and self-control (Silver and Abell 2016; Silver and Silver forthcoming). Another, and perhaps the most important, is that MFT is an interactionist

\footnotetext{
${ }^{2}$ As an anonymous reviewer emphasized, the urge to bind is found in liberal social movements as well, and it may reflect a unique individual-protection-oriented binding morality, and it can give rise to ostracization (Janoff-Bulman and Carnes 2013).
} 
theory of moral behavior. ${ }^{3}$ At its heart is the assumption that personal and environmental characteristics interact with particular moral cuisines to influence attitudes and decision making (Feng et al. 2017; Malka et al. 2016; Smith et al. 2014). As Süssenbach, Rees, and Gollwitzer (2019) explained:

Moral foundations are proposed to elicit intuitive responses (i.e., automatic evaluations) to a set of relevant environmental triggers. . . . In other words, MFT assumes a systematic ("synergistic") person $\times$ situation interaction: People who endorse a specific moral foundation are more attentive toward ("functionally equivalent") cues that indicate a violation or threat of the respective moral standards inherent in that foundation. (p. 123, emphasis in original)

In a series of studies, Süssenbach et al. (2019) have shown that the individualizing foundations interact with the presence of human suffering and need to increase prosocial intentions. For those high on binding foundations, however, the relevant environmental triggers differ. To such people, group cohesion matters more than individual suffering (Haidt and Graham 2009). Indeed, in Süssenbach et al.'s studies, participants scoring high on the binding foundations were either not affected by suffering and need or actually became less prosocial in response to it.

What should be a relevant trigger to those high on binding foundations? Their group leader's example and directives. Binding foundations, by amplifying the moral significance of deference, duty, and solidarity, should bind people to their group and its leader (Haidt 2012; Wolsko, Ariceaga, and Seiden 2016). ${ }^{4}$ Thus, the inclination to adopt the views of leaders should be greater among those whose morality emphasizes binding concerns. If the group leader takes a threat seriously, "binders" should too; if the leader does not, neither should they. The group leader's effect on binders should be especially strong during crises, such as pandemics. Indeed, evidence suggests that binding foundations are activated by the threat of a pathogen-transmitted disease (van Leeuwen et al. 2012). By extension, it is among Americans high on binding foundations that President Trump should be the influencer in chief for social

\footnotetext{
${ }^{3}$ We use the phrase "interactionist theory" to refer to theories that posit interactive effects (or moderation). We are not referring to symbolic interactionism.

${ }^{4}$ Clearly, people follow group leaders for reasons other than binding foundations. Additionally, people are members of many social groups. Groups can also have many authorities and multiple leaders. There are also likely to be many triggers for those high on binding foundations, not just the group leader's example. The influence of a leader should be proportional to his or her leadership role and authority in the group, so presidents should have a disproportionate influence on binders. Additionally, the influence of a trigger should be proportional to its relevance to a specific social group and should increase with the salience of the threat to that particular group. All of this is to say that in the context of a national crisis, one of the most important triggers should be what the president says and does.
}

distancing; it is their behavioral intentions that should be most sensitive to his lead. Our study tests this possibility.

\section{Methods}

\section{Sample}

Like scholars in other disciplines, criminologists increasingly are turning to Amazon Mechanical Turk (MTurk) to study moral behavior and intuitions, because of its diversity and nationwide reach (e.g., Barnum and Solomon 2019; Herman and Pogarsky 2020; Pickett, Roche, and Pogarsky 2018; Silver 2017). Our study's data come from a nationwide opt-in online survey using MTurk, which was fielded on March 28 and 29, 2020. Amazon's MTurk platform allows eligible "workers" to select and perform various tasks for a small financial incentive - in this case, $\$ 2.30$ for completing an online survey. Compared with other data collection modes, online opt-in surveys result in more honest and accurate self-reports (less social desirability bias, less satisficing, less speeding, and no interviewer effects) (Anson 2018; Chang and Krosnick 2009; Weinberg, Freese, and McElhattan 2014). Eligible respondents for our study were MTurk workers 18 years or older who lived in the United States and who, for high-quality respondents, had completed more than 500 previous human intelligence tasks and had 95 percent or higher approval ratings (Peer, Vosgerau, and Acquisti 2014).

From 1,000 respondents, the sample was reduced to an analytic sample of 989 respondents on the basis of listwise deletion for items with missing values ( $<5$ percent). As such, the sample, compared with the 2018 American Community Survey estimates (in parentheses), is 68.8 percent white (72.2 percent), 40.6 percent female (50.8 percent), and 45.4 percent married (47.8 percent); 62.7 percent have a bachelor's degree or higher (30.09 percent); the median income is between $\$ 40,000$ and $\$ 59,999$ (\$61,937); and the average age is 38.38 years (46.92 years). Compared with the 2018 Pew Research Center estimates (in parentheses), 28.6 percent (26 percent) of the sample identify as Republicans. The descriptive statistics are presented in Table 2.

\section{Dependent Variable: Defiance Intentions}

Following other researchers (Antonaccio and Tittle 2008; Barnum and Solomon 2019; Kroneberg, Heintze, and Mehlkop 2010; Nagin and Pogarsky 2001; Paternoster, Jaynes, and Wilson 2018; Pickett et al. 2018; van Gelder and de Vries 2012), we analyze projected offending - in this case, intentions to defy social distancing norms. Behavioral intentions are valid measures of criminality (Pogarsky 2004) and also "are logically better for dealing with causal order," because of their future orientation (Antonaccio and Tittle 2008:493). Additionally, at the time of our survey, respondents' opportunities to defy social distancing directives mostly lay in the future, as governors were just beginning to issue stay-at-home orders.

To measure defiance intentions, we use a mean index based on six Likert-type items (1= strongly disagree, $5=$ strongly 
Table 2. Descriptive Statistics $(n=989)$.

\begin{tabular}{|c|c|c|c|c|c|}
\hline \multirow[b]{2}{*}{ Variable } & \multirow[b]{2}{*}{ Percentage/Mean (SD) } & \multirow[b]{2}{*}{ Range } & \multirow[b]{2}{*}{ Scale $\alpha$} & \multirow[b]{2}{*}{ Factor Loadings } & \multirow{2}{*}{$\begin{array}{c}\text { Correlations with } \\
\text { Dependent Variable } \\
\text { Defiance Intentions }\end{array}$} \\
\hline & & & & & \\
\hline \multicolumn{6}{|l|}{ Dependent variable } \\
\hline Defiance intentions & $1.88(1.13)$ & $\mathrm{I}-5$ & .957 & $.881-.921$ & - \\
\hline \multicolumn{6}{|l|}{ Key independent variables } \\
\hline General faith in Trump & $2.47(1.40)$ & $\mathrm{I}-5$ & .968 & $.923-.958$ & $.574 * * *$ \\
\hline Specific faith in Trump & $2.29(.99)$ & $1-5$ & .898 & $.633-.872$ & $.519 * * *$ \\
\hline Binding foundations & $3.17(.83)$ & $1-5$ & .794 & $.634-.818$ & $.446 * * *$ \\
\hline Individualizing foundations & $3.99(.63)$ & $\mathrm{I}-5$ & .527 & $.636-.658$ & $-.168 * * *$ \\
\hline Low self-control & $2.53(.96)$ & $1-5$ & .875 & $.723-.818$ & $.707 * * *$ \\
\hline Perceived certainty & $2.81(1.79)$ & $\mathrm{I}-7$ & - & - & $.289 * * *$ \\
\hline Personal fear & $2.92(.79)$ & $1-4$ & .903 & $.527-.900$ & .003 \\
\hline Altruistic fear & $3.45(.95)$ & $1-5$ & .912 & $.781-.853$ & $-.122 * * *$ \\
\hline Libertarianism & $0.34(.38)$ & $0-1$ & .739 & $.583-.704$ & $.140 * * *$ \\
\hline Republican & 28.6 & $0-1$ & - & - & $.324 * * *$ \\
\hline Conservativism & $2.69(1.22)$ & $\mathrm{I}-5$ & - & - & $.247 * * *$ \\
\hline \multicolumn{6}{|l|}{ Control variables } \\
\hline Age & 38.38 (I I.42) & $19-79$ & - & - & $-.235 * * *$ \\
\hline Female & 40.6 & $0-1$ & - & - & -.187 \\
\hline White & 68.8 & $0-1$ & - & - & $-.209 * * *$ \\
\hline Education & $4.47(1.26)$ & $1-7$ & - & - & $.277 * * *$ \\
\hline Married & 45.4 & $0-1$ & - & - & $.258 * * *$ \\
\hline Income & 4.31 (I.5I) & $\mathrm{I}-7$ & - & - & .015 \\
\hline News awareness & $3.56(.59)$ & $1-4$ & - & - & $-.083 * *$ \\
\hline
\end{tabular}

$*_{*} p .01$. *** $p<.001$.

agree) that asked about norm-violating behaviors. The items in this scale are listed in Table 3. They load on a single factor (loadings range from .881 to .921) and have high internal reliability $(\alpha=.957)$.

\section{Independent Variables}

Faith in Trump. Two measures of this construct are used in the analysis. First, general faith in Trump is drawn from previous research by Graham et al. (2020) and measures support for the president's leadership views, style, and efficacy. It is a mean index based on five Likert-type items $(1=$ strongly disagree, 5 = strongly agree) that asked respondents about their general attitudes toward President Trump (e.g., "I believe that President Trump will make America great again"). The items have high internal reliability $(\alpha=.968)$ and load on a single factor (loadings range from .923 to .958). The previous research, based on a 2019 national-level YouGov survey, reported similar scale statistics (loadings range from .920 to .974, $\alpha=$.974) (Graham et al. 2020). See Table 4 for the question wording of each item.

Second, specific faith in Trump is a mean index that gauges beliefs and support for President Trump as they related specifically to the COVID-19 crisis. This index is based on 10 Likert-type items ( 1 = strongly disagree, 5 = strongly agree $)$ that asked respondents to report their agreement with statements made by or about Trump during the pandemic (e.g., "President Trump will make America healthy again"). The items load on a single factor (loadings range from .633 to $.872)$ and have high internal reliability $(\alpha=.898)$. See Table 4 for all items used in this scale.

Moral Foundations. We used 20 Likert-type items ( 1 = strongly disagree, 5 = strongly agree) adapted from Graham et al. (2009) to measure respondents' moral foundations (see Appen$\operatorname{dix}$ A), with four items representing each foundation: authority/ respect (loadings range from .650 to $.823, \alpha=.859$ ), purity/ sanctity (loadings range from .843 to $.866, \alpha=.924$ ), ingroup/ loyalty (loadings range from .434 to $.791, \alpha=.721$ ), fairness/ reciprocity (loadings range from .468 to $.773, \alpha=.775$ ), and harm/care (loadings range from .412 to $.507, \alpha=.639$ ). For each foundation, we averaged the four respective items, and then we factor-analyzed the resulting five indices. They loaded on the two theoretically expected factors, corresponding to binding foundations (loadings range from .634 to .818) and individualizing foundations (loadings range from .636 and .658). Accordingly, and following previous research (Malka et al. 2016; Silver and Silver 2017, 2019; Smith et al. 2014; van Leeuwen and Park 2009), we averaged the three group-focused indices (authority/respect, purity/sanctity, and ingroup/loyalty) to generate an overall binding foundations index ( $\alpha=.794)$, and we averaged the two individual-focused indices (fairness/ 
Table 3. Descriptive Statistics on Defiance Intentions Items $(n=989)$.

\begin{tabular}{|c|c|c|c|c|c|c|}
\hline $\begin{array}{l}\text { Thinking About Yourself, How Much Do You Agree or Disagree with } \\
\text { Each of the Following Statements? }\end{array}$ & $\begin{array}{l}\text { Strongly } \\
\text { Disagree }\end{array}$ & Disagree & $\begin{array}{l}\text { Neither Agree } \\
\text { nor Disagree }\end{array}$ & Agree & $\begin{array}{l}\text { Strongly } \\
\text { Agree }\end{array}$ & $\begin{array}{l}\text { Total } \\
\text { Agree }\end{array}$ \\
\hline \multicolumn{7}{|l|}{ Defiance intentions } \\
\hline $\begin{array}{l}\text { Even if the governor of my state orders me to stay at home, I am still } \\
\text { going to go out if I want to. }\end{array}$ & 51.0 & 22.2 & 9.5 & 11.2 & 6.1 & 17.2 \\
\hline $\begin{array}{l}\text { Even with the coronavirus outbreak, I intend on getting together with } \\
\text { friends to socialize. }\end{array}$ & 56.5 & 19.3 & 8.7 & 10.4 & 5.1 & 15.5 \\
\hline $\begin{array}{l}\text { Despite the coronavirus outbreak, if I had a chance to take a fun trip } \\
\text { (e.g., spring break in Florida at the beaches), I would go in a minute. }\end{array}$ & 60.7 & 15.7 & 8.2 & 11.7 & 3.7 & 15.4 \\
\hline $\begin{array}{l}\text { If I had a birthday party or wedding scheduled, I would go ahead and } \\
\text { hold it, despite the coronavirus outbreak. }\end{array}$ & 59.9 & I7.1 & 8.0 & 10.2 & 4.9 & I5.I \\
\hline $\begin{array}{l}\text { I am going to live my life as I always have and am not going to try to } \\
\text { stay six feet away from everyone. }\end{array}$ & 56.8 & 19.0 & 7.6 & 10.2 & 6.4 & 16.6 \\
\hline $\begin{array}{l}\text { Even if I have symptoms, I am still going to go out in public (such as to } \\
\text { a grocery store, work, or park). }\end{array}$ & 60.6 & 17.0 & 6.0 & 10.0 & 6.5 & 16.5 \\
\hline
\end{tabular}

Note: Some percentages may not equal to 100 percent because of rounding.

reciprocity and harm/care) to generate an overall individualizing foundations index $(r=.527)$. See Appendix A for a listing of items and factor loadings.

Low Self-Control. The measure of low self-control is a mean index based on six Likert-type items ( 1 = strongly disagree, 5 = strongly agree) from the Grasmick et al. (1993) scale, each measuring one of the six dimensions of low self-control (see Appendix B for the items). The same six items have been used in previous research to measure low self-control (Herman and Pogarsky 2020; Pickett et al. 2018).

Rational Choice/Deterrence. Because growing evidence shows that risk perceptions and deterrent emotions both influence criminal decision making (Barnum and Solomon 2019; Pickett et al. 2018; van Gelder and de Vries 2012), we measured both. Perceived certainty is an indicator of respondents' perceived probability of death if they become infected with coronavirus, and has seven response options ranging from "under $1 \%$ " to "over 40\%." Personal fear is a mean index based on six items that asked how worried respondents were $(1=$ not worried at all, 4 = very worried) about various aspects of the virus (e.g., "being exposed to the virus," "becoming seriously ill from the virus"). See Appendix B for a listing of the items.

Social Concern. Agnew (2014) theorized the importance of social concerns in crime decisions, and Warr and Ellison (2000) documented the importance of prosocial emotions in behavior. Thus, we include a mean index, altruistic fear, that is based on seven items that asked respondents how often ( 1 = very rarely, $5=$ very often $)$ they worried about the virus making certain people (e.g., "your family members," "doctors and nurses") sick. All items are listed in Appendix B.

\section{Control Variables}

To help isolate the effects of these key independent variables, we include several ideological and sociodemographic controls in the multivariate analyses. First, we control for partisan identification ( $1=$ Republican, 0 = others $)$, and political ideology, with the latter measured ordinally $(1=$ very liberal, $5=$ very conservative), similar to prior research (Baranauskas and Drakulich 2018; Enns and Ramirez 2018). We also control for libertarian views, measured similarly to past research (Filindra and Kaplan, 2016) by counting the number of times in three forced-choice questions respondents chose the libertarian option (e.g., "The less government, the better") over a nonlibertarian one (e.g., "There are more things that the government should be doing") ( $\alpha=$.739). See Appendix B for the items.

The sociodemographic controls include age (in years), sex $(1=$ female, $0=$ male $)$, race $(1=$ white, $0=$ nonwhite $)$, marital status ( $1=$ married, $0=$ other $)$, education (measured ordinally: $1=$ less than high school degree to $7=$ doctoral degree), and 2018 annual household income (measured ordinally: $1=$ $\$ 0$ to $\$ 9,999$ to $7=\$ 100,000$ and over). Additionally, given the news coverage of this crisis, respondent's attention to the news, or news awareness, about COVID-19 was captured on a scale of 1 (not closely at all) to 4 (Very closely).

\section{Analytic Plan}

To assess our overarching research question, the analysis unfolds in three phases. First, we descriptively review the responses to the dependent variable (i.e., defiance intentions) and key independent variables (i.e., general faith in Trump, specific faith in Trump). Second, using ordinary least squares regression, we assess the impact of general faith in Trump on intent to defy social distancing directives. We then explore the impact of the interaction between binding foundations and faith in Trump on respondents' defiance intentions. Third, we repeat this analysis using COVID-19-specific faith in Trump to examine the robustness of the findings. We examined the potential for multicollinearity; the highest variance inflation factor (2.93) is below the recommended cutoffs (Belsley, Kuh, and Welsch 1980), suggesting that multicollinearity is not a concern. 
Table 4. Faith in Trump Responses $(n=989)$.

\begin{tabular}{|c|c|c|c|c|c|c|}
\hline & $\begin{array}{l}\text { Strongly } \\
\text { Disagree }\end{array}$ & Disagree & $\begin{array}{l}\text { Neither Agree } \\
\text { nor Disagree }\end{array}$ & Agree & $\begin{array}{l}\text { Strongly } \\
\text { Agree }\end{array}$ & $\begin{array}{l}\text { Total } \\
\text { Agree }\end{array}$ \\
\hline \multicolumn{7}{|l|}{ General faith in Trump } \\
\hline \multicolumn{7}{|l|}{ How much you agree or disagree with each of the following: } \\
\hline I believe that President Trump will make America great again. & 42.2 & 12.5 & 14.9 & 18.5 & 11.9 & 30.4 \\
\hline $\begin{array}{l}\text { President Trump is } 100 \% \text { correct that we need a wall to make } \\
\text { sure that gang members, criminals, and rapists do not come into } \\
\text { the U.S. }\end{array}$ & 40.1 & 14.6 & 10.8 & 18.8 & 15.7 & 34.5 \\
\hline $\begin{array}{l}\text { President Trump is the only politician who really cares about the } \\
\text { common man. }\end{array}$ & 45.1 & 17.5 & 12.0 & 15.0 & 10.4 & 25.5 \\
\hline $\begin{array}{l}\text { President Trump knows how to protect America against threats } \\
\text { from around the world. }\end{array}$ & 39.7 & 13.1 & 13.2 & 22.0 & 11.8 & 33.8 \\
\hline $\begin{array}{l}\text { I love President Trump's style because he is strong and tells it like } \\
\text { it is. }\end{array}$ & 41.6 & 13.2 & II.I & 19.0 & I5. I & 34.1 \\
\hline \multicolumn{7}{|l|}{ Specific faith in Trump } \\
\hline \multicolumn{7}{|l|}{$\begin{array}{l}\text { There is debate over how well President Donald Trump has handled } \\
\text { the coronavirus outbreak. How much do you agree or disagree with } \\
\text { each of these statements? }\end{array}$} \\
\hline $\begin{array}{l}\text { It is a good idea to follow President Trump's advice for everyone } \\
\text { to pack churches on Easter Sunday, which is on April } 12 \text {. }\end{array}$ & 55.2 & 15.1 & 12.4 & 9.9 & 7.4 & 17.3 \\
\hline $\begin{array}{l}\text { President Trump is correct when he says that the coronavirus is } \\
\text { mostly a hoax used by the Democrats to prevent his reelection. }\end{array}$ & 54.9 & 15.8 & 11.0 & 11.4 & 6.9 & 18.3 \\
\hline $\begin{array}{l}\text { According to President Trump, the coronavirus was invented by } \\
\text { the Chinese and we have every right to call it the "China Virus." }\end{array}$ & 30.9 & 17.8 & 17.8 & 18.6 & 14.9 & 33.5 \\
\hline $\begin{array}{l}\text { President Trump cares more about high stock prices and big } \\
\text { corporations making money than he does about Americans dying } \\
\text { from the coronavirus. }{ }^{a}\end{array}$ & 7.5 & 13.3 & 11.9 & 23.3 & 44.0 & 67.3 \\
\hline $\begin{array}{l}\text { As President Trump says, we need to make sure that the "cure is } \\
\text { not worse than the disease"- that is, we need to open up the } \\
\text { economy soon even if this means some more people get sick and } \\
\text { possibly die. }\end{array}$ & 35.3 & 21.7 & 15.2 & 18.3 & 9.5 & 27.8 \\
\hline $\begin{array}{l}\text { President Obama left Trump a mess, which is why there is a } \\
\text { shortage of protective masks and ventilators. }\end{array}$ & 43.3 & 15.2 & 14.9 & 15.9 & 10.8 & 26.7 \\
\hline $\begin{array}{l}\text { All President Trump cares about is how the coronavirus crisis will } \\
\text { affect his reelection chances, not the health of people now sick } \\
\text { with the disease. }^{\text {a }}\end{array}$ & 11.5 & 10.8 & 12.6 & 24.0 & $4 I .1$ & 65.1 \\
\hline President Trump will make America healthy again. & 36.9 & 15.7 & 17.4 & 17.0 & 13.0 & 30.0 \\
\hline $\begin{array}{l}\text { President Trump's decision to disband the country's National } \\
\text { Security Council's global health office in } 2019 \text { resulted in the U.S. } \\
\text { being unprepared for the coronavirus. }\end{array}$ & 8.9 & 12.1 & 17.3 & 29.1 & 32.6 & 61.7 \\
\hline $\begin{array}{l}\text { If President Trump had acted quicker, fewer people would be sick } \\
\text { or dead from the coronavirus. }{ }^{\text {a }}\end{array}$ & 7.2 & 10.6 & 11.8 & 24.0 & 46.4 & 70.4 \\
\hline
\end{tabular}

Note: Some percentages may not equal to 100 percent because of rounding. a. Reverse coded for analyses.

\section{Results}

About one in six respondents reported defiance intentions. As seen in Table 3, those who expressed agreement that they would violate a social distancing norm ranged from 15.1 percent (item 4 , attending a scheduled wedding or party) to 17.2 percent (item 1, going out during stay-at-home orders). When "neither agree nor disagree" responses are considered, about a fourth of the sample (ranging from 22.5 percent [item 6] to 26.7 percent [item 1]) were open to behavioral defiance. Our calculations (not reported in Table 3) also found that
28.1 percent of the respondents agreed or strongly agreed with at least one of the items regarding defiance intentions.

Table 5 presents two estimated ordinary least squares regression models assessing predictors of these intentions to defy social distancing norms. This analysis explores the implications of holding general faith in Trump. In model 1, which explains 64.6 percent of the variation in defiance intentions, being younger, male, nonwhite, more educated, married, lower income, and less aware of the news about COVID-19 significantly increased intentions to defy social distancing norms. Turning to the criminological variables, personal fear of the 
Table 5. Regression Models for Defiance Intentions with General Faith in Trump.

\begin{tabular}{|c|c|c|c|c|c|c|}
\hline & \multicolumn{3}{|c|}{ Model I } & \multicolumn{3}{|c|}{ Model 2} \\
\hline & $b$ & $S E$ & $\beta$ & $b$ & $S E$ & $\beta$ \\
\hline \multicolumn{7}{|l|}{ Key independent variables } \\
\hline Faith in Trump $\times$ binding foundations & - & - & - & .095 & .023 & $.093 * * *$ \\
\hline General faith in Trump & .222 & .025 & $.275^{* * *}$ & .190 & .026 & $.236 * * *$ \\
\hline Binding foundations & .119 & .036 & $.087 * *$ & .171 & .038 & $.126 * * *$ \\
\hline Individualizing foundations & -.089 & .041 & $-.049 *$ & -.136 & .042 & $-.075 * *$ \\
\hline Low self-control & .538 & .030 & $.458 * * *$ & .520 & .030 & $.443 * * *$ \\
\hline Perceived certainty & .079 & .014 & $.126 * * *$ & .079 & .014 & $.124 * * *$ \\
\hline Personal fear & -.209 & .038 & $-.145^{* * *}$ & -.205 & .037 & $-.143 * * *$ \\
\hline Altruistic fear & -.032 & .031 & -.027 & -.042 & .031 & -.036 \\
\hline Libertarianism & -.108 & .069 & -.036 & -.072 & .069 & -.024 \\
\hline Republican & .001 & .065 & .000 & -.033 & .065 & -.013 \\
\hline Conservativism & -.015 & .024 & -.016 & -.002 & .024 & -.002 \\
\hline \multicolumn{7}{|l|}{ Control variables } \\
\hline Age & -.006 & .002 & $-.064 * *$ & -.006 & .002 & $-.06 \mid * *$ \\
\hline Female & -.137 & .045 & $-.060 * *$ & -.133 & .045 & $-.058 * *$ \\
\hline White & -.113 & .049 & $-.046^{*}$ & -.117 & .049 & $-.048 *$ \\
\hline Education & .106 & .019 & $.118 * * *$ & .093 & .019 & $.104 * * *$ \\
\hline Married & .178 & .049 & $.079 * * *$ & .171 & .048 & $.075^{* * *}$ \\
\hline Income & -.054 & .016 & $-.073 * *$ & -.051 & .016 & $-.068 * *$ \\
\hline News awareness & -.116 & .039 & $-.06 \mid * *$ & -.117 & .038 & $-.06 \mid * *$ \\
\hline Constant & 1.918 & .262 & - & 2.111 & .264 & - \\
\hline Adjusted $R^{2}$ & & .646 & & & .652 & \\
\hline
\end{tabular}

Note: Faith in Trump and binding foundations are both mean centered $* p<.05 . * * p<.01$. ***p $<.001$.

virus was negatively and significantly related to intentions to defy norms $(\beta=-.145, p<.001)$, as deterrence theory would anticipate, but the opposite held for perceiving a greater certainty of death from infection $(\beta=.126, p<.001)$. Altruistic fear, on the other hand, was not significantly related to defiance intentions. Notably, low self-control, which had the strongest effect of any variable in the model, was associated with higher defiance intentions $(\beta=.458, p<.001)$.

Most important, the findings are consistent with the proposed interactionist theory of foundation-based moral behavior. First, general faith in Trump was the second strongest predictor of defiance intentions $(\beta=.275, p<.001)$. Second, the binding and individualizing moral foundations were also significantly associated with these intentions, with binding foundations increasing defiance intentions $(\beta=.087, p<.01)$, and individualizing decreasing reported intentions $(\beta=-.049, p<.05)$. Third, as seen in model 2 in Table 5, the interaction effect of faith in Trump and binding foundations is highly significant and in the predicted direction $(\beta=.093, p<.001)$. Those with greater faith in Trump and who more strongly endorse binding foundations are especially likely to express defiance intentions.

Notably, these effects are mirrored in Table 6, which examines the influence of holding COVID-19-specific faith in Trump on intentions to defy social distancing norms (adjusted $R^{2}=63.8$ percent). First, with regard to criminological factors, low self-control again had the largest effect on defiance intentions $(\beta=.483, p<.001)$, whereas perceived certainty was positively related and personal fear negatively related to such intentions. Furthermore, being younger, male, nonwhite, more educated, married, lower income, and less aware of COVID-19 news coverage significantly influenced intentions to defy social distancing norms. Most important, defiance intentions were significantly higher among those holding specific faith in Trump $(\beta=.227$, $p<.001)$ and among those endorsing binding foundation $(\beta=.099, p<.001)$. And as seen in model 2 in Table 6 , the interaction of these two variables was again significant and in the predicted direction $(\beta=.075, p<.01)$.

Figure 1 graphs the interaction between faith in Trump, both global (Figure 1A) and specific (Figure 1B), and endorsement of binding foundations. The figure shows the relationship between faith in Trump and defiance intentions among those scoring low (below the mean, by 1 standard deviation) and high (above the mean, by 1 standard deviation) on binding foundations. Among both groups - those low and high on binding foundations - both types of faith in Trump are strongly and positively associated with defiance intentions. However, in both panels, the positive relationship between faith in Trump and defiance intentions is much stronger (has a steeper slope) among those scoring higher on binding foundations. The implication is clear: faith in Trump matters - it increases intentions to put oneself and others at risk-but it matters most among those with moral beliefs that emphasize group cohesion (loyalty, respect for authority) over individual protection. 
Table 6. Regression Models for Defiance Intentions Using Specific Faith in Trump.

\begin{tabular}{|c|c|c|c|c|c|c|}
\hline & \multicolumn{3}{|c|}{ Model I } & \multicolumn{3}{|c|}{ Model 2} \\
\hline & $b$ & $S E$ & $\beta$ & $b$ & $S E$ & $\beta$ \\
\hline \multicolumn{7}{|l|}{ Key independent variables } \\
\hline Faith in Trump $\times$ binding foundations & - & - & - & .113 & .032 & $.075^{* *}$ \\
\hline Specific faith in Trump & .261 & .035 & $.227 * * *$ & .240 & .035 & $.210 * * *$ \\
\hline Binding foundations & .135 & .036 & $.099 * * *$ & .173 & .038 & $.128 * * *$ \\
\hline Individualizing foundations & -.054 & .042 & -.030 & -.097 & .044 & $-.053 *$ \\
\hline Low self-control & .566 & .029 & $.483 * * *$ & .553 & .029 & $.47 I * * *$ \\
\hline Perceived certainty & .081 & .014 & $.128 * * *$ & .082 & .014 & $.130 * * *$ \\
\hline Personal fear & -.186 & .038 & $-.130 * * *$ & -.187 & .038 & $-.130 * * *$ \\
\hline Altruistic fear & -.033 & .032 & -.028 & -.043 & .032 & -.036 \\
\hline Libertarianism & -.116 & .070 & -.039 & -.090 & .070 & -.030 \\
\hline Republican & .087 & .063 & .035 & .053 & .064 & .021 \\
\hline Conservativism & -.015 & .025 & -.017 & -.004 & .025 & -.004 \\
\hline \multicolumn{7}{|l|}{ Control variables } \\
\hline Age & -.006 & .002 & $-.064 * *$ & -.006 & .002 & $-.063 * *$ \\
\hline Female & -.147 & .046 & $-.064 * *$ & -.143 & .046 & $-.062 * *$ \\
\hline White & -.108 & .050 & $-.044^{*}$ & -.110 & .049 & $-.045^{*}$ \\
\hline Education & .108 & .019 & $.121 * * *$ & .101 & .019 & $.113 * * *$ \\
\hline Married & .184 & .049 & $.081 * * *$ & .178 & .049 & $.078 * * *$ \\
\hline Income & -.052 & .016 & $-.069 * *$ & -.050 & .016 & $-.066 * *$ \\
\hline News awareness & -.107 & .039 & $-.056 * *$ & -.107 & .039 & $-.056 * *$ \\
\hline Constant & 1.563 & .262 & - & 1.744 & .266 & - \\
\hline Adjusted $R^{2}$ & \multicolumn{3}{|c|}{.638} & \multicolumn{3}{|c|}{.642} \\
\hline
\end{tabular}

Note: Faith in Trump and binding foundations are both mean centered.

$*_{p}<.05 . * * p<.01$. ***p $<.001$.

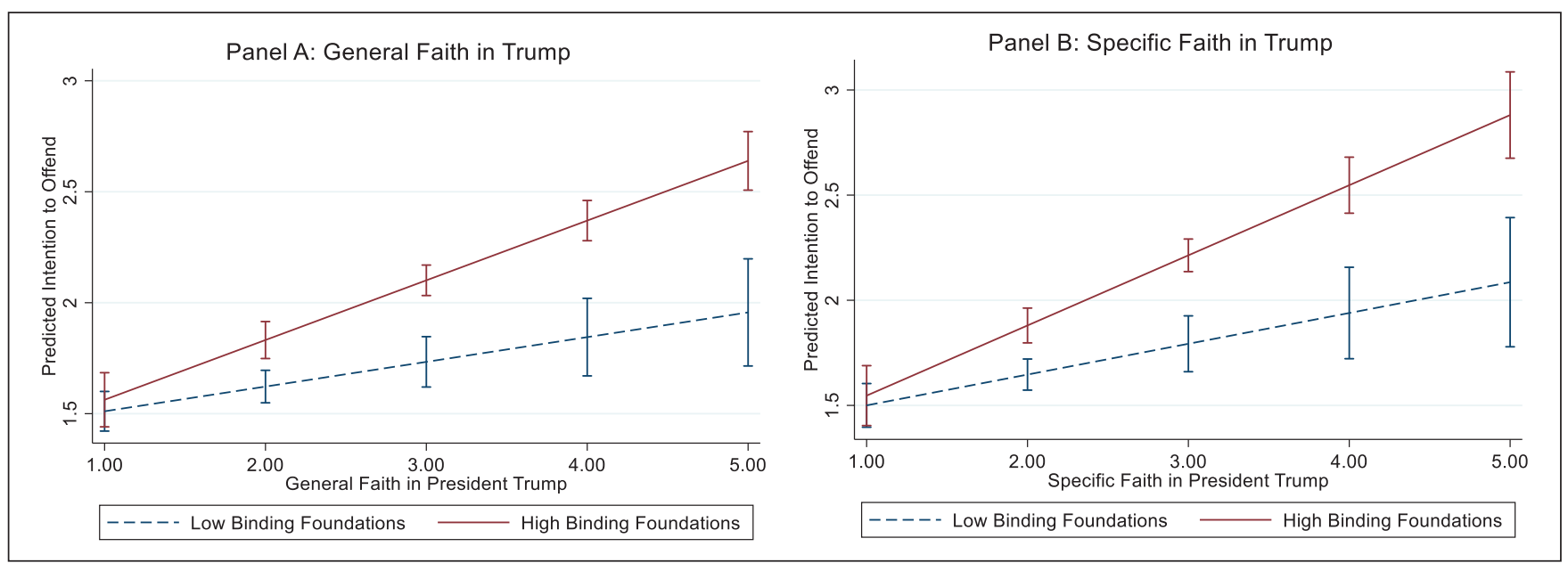

Figure I. Predicted Intentions to Defy Social Distancing Directives: Interaction of Faith in Trump with Binding Moral Foundations. Note: The figure shows adjusted predictions with 95 percent confidence intervals. "Low" and "high" binding foundations are defined as I standard deviation below and above the mean. General and specific faith in Trump are both mean indices with values ranging from I to 5 .

As a check on the robustness of the results reported in Tables 5 and 6, we reestimated the models after controlling for state policy decisions that were enacted in each state at the time the survey was fielded. The respondents' ZIP codes were used to code their states of residence. A database from the University of Washington made available online provided for each state's social distancing regulations, including having a stay-at-home order, the closure of nonessential businesses, and having restrictions on gatherings (Fullman et al. 2020). Using the day the survey was fielded (March 28) as a temporal cutoff point, three dummy indicators were created signifying the statewide presence of a stay-at-home order $(1=y e s, 0=n o)$, the closure of nonessential businesses $(1=y e s, 0=n o)$, and having any restriction on gatherings $(1=y e s, 0=n o)$. These 
statewide policies had no effect on the models presented in Table 5 or 6 , and the rest of the findings were substantively unchanged.

\section{Discussion}

A new national pride will stir our souls, lift our sights, and heal our division. . . . Together, we will make America great again. -President Donald Trump (January 20, 2017), in his inaugural address

Since assuming office, President Trump has taken complete control of the Republican Party. He has characterized politicians who challenged his authority as traitors. "They are lying \& cheating like never before in our Country's history in order to destabilize the United States of America," he has tweeted, while asking his followers: "Arrest for Treason?" (D. Jackson 2019). The president has earned deep allegiance from his base, who don MAGA hats and attend his political rallies. He has tried repeatedly to manipulate and exploit the groupcentered moral and emotional instincts of his followers (Haner et al. 2020; Yong 2020), who are already prone to racism and nativism (Hooghe and Dassonneville 2018), by telling them that it is permissible to put their group first, to despise political correctness, to resent immigrants who purportedly threaten their safety and seek to turn the United States into a nation no longer demographically and culturally white, and to see Obama and his liberal-elite cronies as unpatriotic socialists (Hochschild 2018; Jardina 2019; Kaufmann 2018; Maxwell and Shields 2019). Above all else, President Trump has emphasized the importance of his authority; "I'll be the oversight," he has said about the coronavirus stimulus bill (Steib 2020); "I alone can fix it," he has said about America (Rucker and Leonnig 2020:1); "When somebody is president of the United States, your authority is total," he has said about his ability to override states' stay-at-home orders (Liptak and Hoffman 2020).

\section{The Faith-in-Trump Effect}

All of this - the attacks on rivals' loyalty and patriotism, the emphasis on putting country first, the calls for devotion and for total faith in his authority - set the moral stage for the disastrous effects of President Trump's downplaying of the coronavirus. Had measures been taken one week sooner, Columbia University researchers estimate that the United States could have saved more than 35,000 lives and prevented more than 600,000 cases of COVID-19 in the United States alone (Pei, Kandula, and Shaman 2020). In January, U.S. Department of Health and Human Services secretary Alex Azar briefed President Trump about the dangers of the coronavirus, but the president saw him as an "alarmist," he said (Boot 2020). Peter Navarro, President Trump's trade adviser, also warned in January "that a coronavirus pandemic could cost the country trillions of dollars and endanger millions of Americans" (Visser 2020). His warning, too, was treated with skepticism by aides to the president and, it appears, by President Trump himself, who claimed at the time that the outbreak was "totally under control," was "one person coming from China," and would have "a very good ending" (Boot 2020; Visser 2020). Consistent with President Trump's messages downplaying the coronavirus threat, Republican states (Ohio being an exception) were tardy in imposing social distancing mandates and engaged in less social distancing (Adolph et al. 2020; Allcott et al. 2020). Public opinion polls have repeatedly shown that Republicans have been far less likely than Democrats to see the coronavirus as posing a threat to them personally or to others (NPR/ PBS NewsHour/Marist Poll 2020; Pew Research Center 2020; Yahoo News/YouGov 2020).

Our findings go further than existing polls, however, and show that it is not partisanship itself that matters. Instead, the evidence points to the consequences of having "faith in Trump" at this particular historical juncture. Controlling for partisan identification, political ideology, as well as a host of other variables, such as libertarianism, we find that having faith in President Trump generally and having faith in President Trump's handling of the coronavirus specifically are both powerful predictors of intentions to defy social distancing directives. Those who believe in President Trump are more likely to say they will endanger themselves and their fellow citizens by leaving their homes, going on trips, attending social events, and getting within six feet of others. In fact, they are more likely to say they will do these things even if they have symptoms. This association between faith in President Trump and defiance of social distancing is illustrated in the protests across the country of various states' stayat-home orders. Demonstrators, standing unmasked and side by side (not the recommended six feet apart), proudly don MAGA hats and waive Trump/Pence flags while demanding that governors reopen states (Burnett and Slodysko, 2020). We return to this issue in the concluding paragraphs.

\section{Moral Foundations and the Trump Effect}

Our findings also show that President Trump's self-proclaimed "cheerleading" matters more to some kinds of individuals than to others. Faith in Trump, both general and specific, is most strongly associated with intentions to defy social distancing directives among individuals who are high on binding foundations-whose moral concerns center on respect for authority, group cohesion, obedience, and self-sacrifice. Theoretically, per MFT (Graham et al. 2009; Haidt 2012), these are the people who should be most sensitive to their group leader's lead, because they seek tight integration into a strong group under a strong leader (Haidt and Graham 2009:371). Our findings are consistent with that theory. Our interactive findings are also consistent with a growing body of research that supports an "interactionist account ... of foundation-based 
moral behavior" (Süssenbach et al. 2019:130). Studies have found that different moral foundations, binding or individualizing, interact with political identity (Malka et al. 2016), moral identity (Smith et al. 2014), and visual cues of suffering (Süssenbach et al. 2019) to influence attitudes and behavior. Our study is the first, to our knowledge, to show that moral foundations also interact with views of group leaders, particularly in the context of a national crisis. The results suggest that, for better or worse, in crisis, such as pandemics, binding foundations bind individuals to their leaders; if their leaders downplay a viral threat and call for opening the country up for business, binders will follow suit.

More generally, our findings show that moral foundations also have main effects on social distancing intentions. Those who endorse binding foundations are more defiant of social distancing, whereas those who endorse individualizing foundations - the foundations associated with empathy, compassion, altruism, and sensitivity to human suffering (Graham et al. 2009; Haidt 2012; Süssenbach et al. 2019) - are more likely to say they will engage in social distancing. These findings not only provide support for MFT but also reaffirm behavioral economic findings showing that endorsement of individualizing over binding foundations increases prosocial behavior (Clark et al. 2017). A key theoretical and empirical implication is that criminologists would do well to incorporate MFT in their studies of crime-related decision making, attitudes, and behavior (Silver 2017; Silver and Abell 2016; Silver and Silver 2017; Vaughan, Holleran, and Silver 2019).

\section{Relevance of Criminology}

Our analysis also reveals that other factors, highlighted by criminological theories, are associated significantly with intent to defy social distancing directives. Consistent with Gottfredson and Hirschi's (1990) perspective, low self-control has general effects, increasing defiance intentions. Specifically, those with less self-control are more likely to say that they will put themselves and others at risk by going out, even if they have symptoms. In fact, low self-control was the strongest predictor of social distancing defiance in our study. However, given the ongoing debate about the measurement of self-control (Burt 2020), additional studies are needed that replicate our study using alternative measures of the concept.

In contrast, and somewhat surprisingly, we find no evidence that social concerns (Agnew 2014) - as measured by altruistic fear (Drakulich 2015; Warr and Ellison 2000) influence defiance intentions. At the bivariate level, there is a significant negative association between altruistic fear and defiance, but it goes away in the multivariate models. Thus, one possibility is that the association between altruistic fear and social distancing is spurious, perhaps reflecting the confounding influence of individualizing foundations, which increase altruistic emotions (Haidt 2012; Süssenbach et al. 2019). Future research is needed that explores this possibility and, more generally, that examines the direct and indirect effects of moral foundations on deviant behavior.

The findings herein are also relevant to deterrence theory, suggesting that deterrent perceptions and emotions can have divergent effects that are perhaps contextually dependent. Prior research has shown that the only deterrence perception that is consistently negatively related to offending is perceived certainty (Paternoster 2018; Paternoster and Bachman 2013) - the so-called certainty principle (Apel 2013:73). Surprisingly, in our study, the perceived certainty of death upon infection was positively associated with defiance intentions - those who perceived greater risk were more likely to say they would defy social distancing directives. At first blush, this seems to contradict deterrence theory. However, there are at least two possible explanations. First, the finding may reflect the question wording, which asked about the probability of death, conditional on infection, but did not ask about the probability of infection. Respondents who perceived the coronavirus to be deadlier also may have perceived infection to be less likely. Second, unlike for the certainty of arrest - the typical focus in deterrence researchthere is an abundance of information about the coronavirus's mortality rate. Thus, overestimating the certainty of death may reflect carelessness and inattention, if not motivated ignorance. The implication is that the effect of certainty perceptions on decision making may vary depending on the information environment.

What does not contradict deterrence theory in our study, however, is the effect of deterrent emotions. One of the main advancements in recent years in the literature on criminal decision making has been the recognition that deterrent emotions matter (Barnum and Solomon 2019; Pickett et al. 2018; van Gelder and de Vries 2012). Indeed, studies that have included both cognitive and emotional measures have found stronger effects of deterrent emotions, suggesting that "deterrence ultimately may be emotional" (Pickett et al. 2018). Our findings are consistent with that interpretation. We find that personal fear of coronavirus consequences is significantly and negatively related to intentions to defy social distancing directions. In other words, independent of certainty perceptions and other factors, those who are more afraid of infection are more willing to follow health guidelines. The implication is that, after decades of focusing exclusively on deterrent cognitions - perceptions of certainty, severity, and celerity (Apel 2013) - there is now "a general need for the field to devote greater attention to theorizing and testing the role of deterrent emotions in crime causation" (Pickett et al. 2018:46).

\section{Limitations and Future Research}

Four limitations of our analysis bear mention, which provide opportunities for future research. First, like much recent research (Barnum and Solomon 2019; Pickett et al. 2018; Silver 2017), we use an MTurk sample, which, although diverse and national in scope, is nonetheless a convenience sample. 
That means our findings may not generalize to the American population, but definitive conclusions about their generalizability must await replications with probability samples. For example, our sample is more educated than the general population, which may give rise to the unusual finding of a positive relationship between education and defiance intentions - we can only speculate this is due to overconfidence in their ability to engage socially without contracting the virus.

Second, our outcome variable measured behavioral intentions, not behavior. This, too, is quite common in criminological studies (Antonaccio and Tittle 2008; Barnum and Solomon 2019; Paternoster et al. 2017), and for good reason (Pogarsky 2004). Nonetheless, it is important to know whether similar findings emerge in models predicting behavior. Thus, an important direction for future research is to replicate our study using data on individuals' actual social distancing practices. Cell phone data hold promise for this purpose (see Gollwitzer et al. 2020; Sharkey 2020).

Third, as with any research, our study could have omitted relevant variables. For example, in a Vox news story, Sharkey (2020) analyzed macro-level data and found that counties with more global warming deniers (a proxy for scientific literacy) were less likely to social distance. Whether this or other variables matter at the individual level and would attenuate the effects of general and specific faith in Trump remains to be seen. Sharkey did not include a contemporaneous measure of faith in Trump, for example, so his findings may have been spurious. In our study, the Trump effects are large and robust, and they render partisanship and political beliefs (conservatism, libertarianism) nonsignificant. The unique interaction effects with binding moral foundation also are unlikely to be reduced by the inclusion of other variables. In addition, it is possible that our measure of faith in Trump captures those who reject the media portrayal of the virus's seriousness or those who seek to achieve herd immunity. However, given the robust results using a COVID-19specific measure and a more general measure of faith in Trump, we do not believe this to be the case. Still, we welcome future research that adds measures to our design and can increase the explained variation beyond 65 percent.

Fourth and perhaps most important, it remains an empirical question whether the results based on data collected at the end of March would emerge now (beginning of September) or at later dates. It is possible to find among President Trump's wealth of communications cautionary comments about the pandemic. After our survey was completed, for example, the president extended the federal social distancing recommendation to remain in place until April 30 (Santucci, Fritze, and Subramanian 2020). Still, ample reasons exist to conclude that Trump's effect on social distancing intentions has, in the least, remained stable.

Supportive evidence comes from a macro-level study (not yet peer reviewed) led by Yale psychologist Anton Gollwitzer and colleagues (2020) that assessed geo-tracking data drawn from 17 million smartphone users from March 9 until May 8.
They reported 16 percent less physical distancing in U.S. counties that voted for Donald Trump over Hillary Clinton in the 2016 presidential election. Lower physical distancing also was found for counties that watched more conservative media (Fox News) and in states that have higher Trump approval. Most notable, although the researchers had made the preregistered prediction that the effects of voting for President Trump would decrease over time "as the pandemic worsened and people became more aware of the dangers of COVID-19," they "found the opposite." "As the pandemic progressed," noted Gollwitzer et al., "counties' percentage of votes for Trump over Clinton became an increasingly negative predictor of physical distancing in terms of both general movement and visits to nonessential services." This partisan divide, which we measure on the individual level by faith in Trump, has disturbing consequences. Lower levels of social distancing in "strongly pro-Trump counties ... [were] associated with a $27 \%$ higher growth rate in COVID-19 infections."

The stability, if not deepening, of the faith in Trump effects is likely attributable to the president's skill in influencing his followers. In messaging about the pandemic, the president has continually downplayed the need for Americans to engage in social distancing and has often encouraged defiance of restrictions. Consider what has transpired since our survey was conducted. President Trump's tweets have repeatedly instructed followers to "liberate" themselves against Democratic governors' stay-at-home orders, which he characterized as "too tough"; his tweets were messages in support of demonstrators in states such as Michigan and Minnesota (Chalfant and Samuels 2020; Stanley-Becker, Olorunnip, and Kim 2020). At these rallies, protesters displayed numerous signs expressing their defiance of social distancing norms (e.g., "We will not comply").

Indeed, rather than advise patience and prudence, the president has speculated about treatments and overstated the scientific progress of developing a vaccine. Who can forget his urging Americans to take the unproven drug hydroxychloroquine and then claiming that he was doing so (Cha and McGinley, 2020)? Or his suggesting that a "tremendous" ultraviolet light or ingesting a disinfectant might kill the coronavirus, the latter remark leading to increased calls to state poison control centers (Foley 2020; Zhao 2020)? He has also constantly called to reopen the economy, churches, schools, and even meatpacking plants ravaged by infections and deaths (see, e.g., Strauss 2020; Sun and Dawsey 2020; Trumpka 2020). President Trump moved the Republican national convention from Charlotte, North Carolina, to Jacksonville, Florida, because Governor Roy Cooper refused to guarantee that the gathering could be held "with no face masks and social distancing" (Sullivan and Nobles, 2020). Rising health concerns in Jacksonville led to the gathering's being returned to Charlotte, with much of the convention being held remotely. He also held a campaign rally with 6,200 people in Tulsa, Oklahoma, which subsequently "likely contributed" to a record-high surge of cases in the weeks following the rally 
(quoted in Murphy 2020). Most salient perhaps, the president has failed to practice social distancing in public appearances. With rare exceptions, he has stubbornly refused to wear a mask - the ultimate symbol of responsible social distancing. He has done so despite 34 states' passing laws making the wearing of masks mandatory in certain public and work settings (Fernandez 2020). Only recently (five months into the pandemic), after his slipping polling numbers, the urging of his political advisers, and GOP leadership changing their position, he has modified his stance, claiming that mask wearing is "patriotic" (Baker 2020).

\section{Conclusion}

As the nation opens up more and more, compliance with social distancing laws and informal norms will be consequential; public health is at stake (Gollwitzer et al. 2020; Sharkey and Wood 2020). We (the authors) have all experienced instances in which individuals have violated social distancing in our spaces, such in supermarkets or along jogging trails. Collective examples of mass normative defiance are even more concerning for public health, such as patrons crowding into bars in Wisconsin after the state's high court struck down Governor Tony Evers's “safer at home" order (a ruling "praised by Trump"), mass protests of the police in major cities across the country (Dave et al. 2020), and, on Memorial Day weekend, unmasked poolparty attendees packed together in Lake of the Ozarks, Missouri (Associated Press 2020; Buchanan, Bui, and Patel 2020; Levensen and Jackson 2020). In past times, we might have expected a President Bush or Clinton to urge us to unify as a nation and to pursue the common good through safe interactions. In the current context, however, our data suggest that a charismatic and influential leader is evoking social distancing defiance, especially among those bound to his authority. Faith in Trump matters.

Appendix A. Moral Foundations: Question Wording, Factor Loadings, and Reliabilities.

\begin{tabular}{|c|c|c|c|}
\hline Measure & $\begin{array}{l}\text { Within-Scale } \\
\text { Factor Loadings }\end{array}$ & $\begin{array}{l}\text { Beth } \\
\text { Facto }\end{array}$ & $\begin{array}{l}- \text { Scale } \\
\text { adings }\end{array}$ \\
\hline \multicolumn{4}{|l|}{ Binding foundations } \\
\hline Purity/sanctity $(\alpha=.924)$ & & .717 & .013 \\
\hline People should not do things that are disgusting, even if no one is harmed. & .843 & & \\
\hline Some acts are wrong simply because they are disgusting. & .865 & & \\
\hline I would call some acts wrong on the grounds that they are unnatural. & .854 & & \\
\hline Some acts are wrong simply because they violate the standards of purity and decency. & .866 & & \\
\hline Authority/respect $(\alpha=.859)$ & & .818 & .010 \\
\hline Respect for authority is something all children need to learn. & .650 & & \\
\hline $\begin{array}{l}\text { When the government makes laws, those laws should always respect the traditions and } \\
\text { heritage of the country. }\end{array}$ & .771 & & \\
\hline People should never curse the founders or early heroes of their country. & .823 & & \\
\hline People should never disrespect their bosses, teachers, or professors. & .807 & & \\
\hline Ingroup/loyalty $(\alpha=.72 I)$ & & .634 & -.015 \\
\hline People should always put their group's interests above their own personal interests. & .791 & & \\
\hline Loyalty to one's group is more important than one's individual concerns. & .790 & & \\
\hline $\begin{array}{l}\text { The government should strive to improve the well-being of people in our nation, even if } \\
\text { it sometimes happens at the expense of people in other nations. }\end{array}$ & .434 & & \\
\hline I would never turn a family member in for committing a crime. & .457 & & \\
\hline \multicolumn{4}{|l|}{ Individualizing foundations } \\
\hline Harm/care $(\alpha=.639)$ & & .140 & .636 \\
\hline If I saw a mother slapping her child, I would be outraged. & .507 & & \\
\hline It can never be right to kill a human being. & .412 & & \\
\hline Compassion for those who are suffering is the most crucial virtue. & .664 & & \\
\hline The government must first and foremost protect all people from harm. & .622 & & \\
\hline Fairness/reciprocity $(\alpha=.775)$ & & -.108 & .658 \\
\hline $\begin{array}{l}\text { If a friend wanted to cut in with me on a long line, I would feel uncomfortable because it } \\
\text { wouldn't be fair to those behind me. }\end{array}$ & .468 & & \\
\hline Justice, fairness, and equality are the most important requirements for a society. & .707 & & \\
\hline $\begin{array}{l}\text { When the government makes laws, the number one principal should be ensuring that } \\
\text { everyone is treated fairly. }\end{array}$ & .773 & & \\
\hline People should always treat others fairly and equally. & .729 & & \\
\hline
\end{tabular}

a. Promax-rotated. 
Appendix B. Survey Items.

Variable

Measure

Low self-control

Thinking about yourself, how much do you agree or disagree with each of the following statements? (Response options: strongly disagree, disagree, neither agree nor disagree, agree, strongly agree)

I. I often act on the spur of the moment without stopping to think.

2. I often do whatever brings me pleasure here and now, even at the cost of some distant goal.

3. I frequently try to avoid projects that I know will be difficult.

4. I try to look out for myself first, even if it means making things difficult for other people.

5. I lose my temper pretty easily.

6. When I'm really angry, other people better stay away from me.

Personal fear

Thinking about the coronavirus, how worried are you about each of the following? (Response options: not worried at all, not too worried, somewhat worried, very worried)

I. Being exposed to the virus

2. Having to quarantine after exposure

3. Becoming sick from the virus

4. Becoming seriously ill from the virus

5. Having long-term health problems due to the virus

6. Dying from the virus

Altruistic fear

How often or rarely do you WORRY about the coronavirus making the following people SICK? (Response options: very often, often, sometimes, rarely, very rarely)

I. Your family members

2. Your friends

3. Elderly people you know

4. Your neighbors

5. Doctors and nurses

6. People across America

7. People in other countries

Libertarianism

Which of these statements comes CLOSEST to your view?

A) The main reason government has become bigger over the years is because it has gotten involved in things that people should do for themselves.

B) Government has become bigger because the problems we face have become bigger.

Which of these statements comes CLOSEST to your view?

A) We need the government to handle today's complex economic problems.

Which of these statements comes CLOSEST to your view?

B) The free market can handle these problems without government being involved.

A) There are more things that the government should be doing.

B) The less government, the better.

\section{ORCID iDs}

Amanda Graham (iD https://orcid.org/0000-0002-7474-2539

Justin T. Pickett (iD) https://orcid.org/0000-0002-8519-2659

Melissa M. Sloan (iD https://orcid.org/0000-0001-7750-6382

\section{References}

Adolph, Christopher, Kenya Amano, Bree Bang-Jensen, Nancy Fullman, and John Wilkerson. 2020. "Pandemic Politics: Timing State-Level Social Distancing Responses to COVID19." Unpublished paper, Department of Political Science, University of Washington. Retrieved August 27, 2020. https:// www.medrxiv.org/content/10.1101/2020.03.30.20046326v1.
Agnew, Robert. 2014. "Social Concern and Crime: Moving beyond the Assumption of Simple Self-Interest-2013 Presidential Address to the American Society of Criminology." Criminology 52(1):1-32.

Allcott, Hunt, Levi Boxell, Jacob C. Conway, Matthew Getzkow, Michael Thaler, and David Y. Yang. 2020. "Polarization and Public Health: Partisan Differences in Social Distancing during COVID-19." NBER Working Paper No. 26946. Cambridge, MA: National Bureau of Economic Research.

Anson, Ian G. 2018. "Taking the Time? Explaining Effortful Participation among Low-Cost Online Survey Participants." Research \& Politics 5(3):1-18.

Antonaccio, Olena, and Charles R. Tittle. 2008. "Morality, SelfControl, and Crime." Criminology 46(2):479-510. 
Apel, Robert. 2013. "Sanctions, Perceptions, and Crime: Implications for Criminal Deterrence." Journal of Quantitative Criminology 29:67-101.

Associated Press. 2020. "Wisconsin Bars Reopen after Court Ruling Praised by Trump." CNBC, May 14. Retrieved August 27, 2020. https://www.cnbc.com/2020/05/14/wisconsin-barsreopen-after-court-ruling-praised-by-trump.html.

Baker, Peter. 2020. "Trump, in a Shift, Endorses Masks and Says Virus Will Get Worse.” The New York Times, July 28. Retrieved August 27, 2020. https://www.nytimes.com/2020/07/21/us/ politics/trump-coronavirus-masks.html.

Baker, Peter, and Glenn Thrush. 2017. "Less Tweeting, Lawyers Beg. 'Covfefe,' the President Says." The New York Times, June 1. Retrieved August 27, 2020. https://www.nytimes. com/2017/05/31/us/politics/trump-twitter-russia.html.

Baranauskas, Andrew J., and Kevin M. Drakulich. 2018. "Media Construction of Crime Revisited: Media Types, Consumer Contexts, and Frames of Crime and Justice." Criminology 56(4):679-714.

Barnum, Timothy C., and Starr J. Solomon. 2019. "Fight or Flight: Integral Emotions and Violent Intentions." Criminology 57(4):659-86.

Behrmann, Savannah. 2020. "Nunes Walks Back 'Go to Your Local Pub' Comments, Blames Media for Creating Coronavirus Panic." USA Today, March 16. Retrieved August 27, 2020. https://www.usatoday.com/story/news/politics/2020/03/16/ coronavirus-devin-nunes-walks-back-go-your-local-pub-comments/5065469002/.

Belsley, David A., Edwin Kuh, and Roy E. Welsch. 1980. Regression Diagnostics: Identifying Influential Data and Sources of Collinearity. New York: John Wiley.

Boot, Max. 2020. "The Worst President. Ever." The Washington Post, April 5. Retrieved August 27, 2020. https://www.washingtonpost.com/opinions/2020/04/05/worst-president-ever/.

Breuninger, Kevin. 2020. “Trump Wants 'Packed Churches' and the Economy Open Again on Easter Despite the Deadly Threat of Coronavirus." CNBC Politics, March 24. Retrieved August 27, 2020. https://www.cnbc.com/2020/03/24/coronavirusresponse-trump-wants-to-reopen-us-economy-by-easter.html.

Brewington, Autumn. 2020. "The Queen Gives a Stirring Tutorial in Leadership." The Washington Post, April 6. Retrieved August 27, 2020. https://www.washingtonpost.com/opinions/2020/04/06/with-britain-crisis-queen-elizabeth-breaksher-usual-silence/.

Brownstein, Ronald. 2020a. "Coronavirus Is Dividing Blue Cities from Their Red States.” CNN. Retrieved August 27, 2020. https:/www.cnn.com/2020/03/31/politics/red-states-blue-cities-coronavirus/index.html.

Brownstein, Ronald. 2020b. "Red and Blue American Aren't Experiencing the Same Pandemic." The Atlantic, March 20. Retrieved August 27, 2020. https://www.theatlantic.com/politics/archive/2020/03/how-republicans-and-democrats-thinkabout-coronavirus/608395/.

Buchanan, Larry, Quoctrung Bui, and Jugal K. Patel. 2020. "Black Lives Matter May Be the Largest Movement in U.S. History." The New York Times, July 3. Retrieved August 27, 2020. https:/www.nytimes.com/interactive/2020/07/03/us/georgefloyd-protests-crowd-size.html.

Burke, Daniel. 2020a. "Police Arrest Florida Pastor for Holding Church Services Despite Stay-at-Home Order." CNN,
March 30. Retrieved August 27, 2020. https:/www.cnn. com/2020/03/30/us/florida-pastor-arrested-river-church/index. html.

Burke, Daniel. 2020b. "Second Pastor Charged with Violating Public Orders Says Church Doors Will Still Be Open on Sunday." CNN, April 1. Retrieved August 27, 2020. https:// www.cnn.com/2020/03/31/us/louisiana-pastor-arrest-tonyspell/index.html.

Burnett, Sara, and Brian Slodysko. 2020. "Pro-Trump Protesters Push Back on Stay-at-Home Orders.” PBS NewsHour, April 17. Retrieved August 27, 2020. https://www.pbs.org/newshour/nation/pro-trump-protesters-push-back-on-stay-at-homeorders.

Bush, George W. 2003. "Executive Order 13295: Revised List of Quarantinable Communicable Diseases.” Retrieved August 27, 2020. https://www.cdc.gov/sars/quarantine/exec-2004-04-03. pdf.

Burt, Callie H. 2020. "Self-Control and Crime: Beyond Gottfredson and Hirschi's Theory." Annual Review of Criminology 3:4373.

Cha, Ariana Eunjung, and Laurie McGinley. 2020. “Antimalaria Drug Touted by President Trump is Linked to Increased Risk of Death in Coronavirus Patients, Study Says." The Washington Post, May 22. Retrieved August 27, 2020. https://www.washingtonpost.com/health/2020/05/22/hydroxychloroquine-coronavirus-study/.

Chalfant, Morgan, and Brett Samuels. 2020. "Trump Defends Demonstrators Protesting Social Distancing Restrictions." The Hill, April 17. Retrieved August 27, 2020. https://thehill.com/homenews/administration/493445-trump-defendsdemonstrators-protesting-social-distancing-restrictions?fbclid =IwAR1GaCjwZVtoFtFA6PROw9wm0T87cebDfSRZ8kK-J pWXUfjIkBLC9CT3-yw.

Chang, Linchiat, and Jon A. Krosnick. 2009. "National Surveys via RDD Telephone Interviewing versus the Internet: Comparing Sample Representativeness and Response Quality." Public Opinion Quarterly 73(4):641-78.

Cillizza, Chris. 2020. "11 Times Donald Trump Has 'Belittled' Coronavirus.” CNN Politics, April 1. Retrieved August 27, 2020. https://www.cnn.com/2020/04/01/politics/donald-trumpcoronavirus-mike-pence/index.html.

Clark, C. Brendan, Jeffrey A. Swails, Heidi M. Pontinen, Shannon E. Bowerman, Kenneth A. Kriz, and Peter S. Hendricks. 2017. "A Behavioral Economic Assessment of Individualizing versus Binding Moral Foundations." Personality and Individual Differences 112(1):49-54.

Cohen, Jeffrey E. 1995. "Presidential Rhetoric and the Public Agenda." American Journal of Political Science 39(1):87-107.

Cohen, Jeffrey E. 1997. Presidential Responsiveness and Public Policy. Ann Arbor: University of Michigan Press.

Cohen, Jeffrey E., and John A. Hamman. 2003. "The Polls: Can Presidential Rhetoric Affect the Public's Economic Perceptions?" Presidential Studies Quarterly 33(2):408-22.

Cullen, Francis T., Edward J. Latessa, and Cheryl Lero Jonson. 2012. "Assessing the Extent and Sources of NCAA Rule Infractions: A National Self-Report Study of Student-Athletes." Criminology and Public Policy 11(4):665-706.

Dave, Dhaval M., Andrew I. Friedson, Kyutaro Matsuzawa, Joseph J. Sabia, and Samuel Safford. 2020. "Black Lives Matter Protests, Social Distancing, and COVID-19.” NBER Working 
Paper No. w27408. Cambridge, MA: National Bureau of Economic Research.

Dean, Mensah M., and Ellie Rushing. 2020. "When People Defy Social Distancing Directives during Pandemic, What Are Others to Do?" The Philadelphia Inquirer, March 31. Retrieved August 27, 2020. https://www.inquirer.com/health/ coronavirus/coronavirus-covid-19-social-distancing-violatorsphiladelphia-20200331.html.

DePaolo, Joe. 2020. "5 Key Moments from Trump's Off the Rails Coronavirus Interview on Fox \& Friends." Retrieved August 27, 2020. https://www.mediaite.com/trump/5-key-momentsfrom-trumps-off-the-rails-coronavirus-interview-on-foxfriends/.

Donovan, Joan. 2019. "How Trump Put Himself in Charge of Twitter's Decency Standards." The Washington Post, July 19. Retrieved August 27, 2020. https://www.washingtonpost.com/ outlook/2019/07/19/how-trump-put-himself-charge-twittersdecency-standards/.

Drakulich, Kevin M. 2015. "Concerns for Self or Family? Sources of and Responses to Altruistic Fear." Journal of Interpersonal Violence 30(7):1168-1207.

Druckman, James N., and Lawrence R. Jacobs. 2009. "Presidential Responsiveness to Public Opinion." Pp. 160-81 in The Oxford handbook of the American presidency, edited by G. C. Edwards and W. G. Howell. New York: Oxford University Press.

Enns, Peter K., and Mark D. Ramirez. 2018. "Privatizing Punishment: Testing Theories of Public Support for Private Prison and Immigration Detention Facilities." Criminology 56(3):546-73.

Evon, Dan. 2020. "Is This Timeline of Trump's Coronavirus Response Accurate?" Snopes, March 18. Retrieved August 27, 2020. https://www.snopes.com/fact-check/timeline-trumpcovid19-responses/.

Feng, Qiudi, Yan Xu, Ruijie Xu, and Enhan Zhang. 2017. "Moral Foundations Tell Us Why Guilt Induces Unfair Allocation in Multi-party Interactions." Asian Journal of Social Psychology 20:191-200.

Fernandez Marisa. 2020. "The States Where Face Coverings Are Mandatory." Axios, August 8. Retrieved August 27, 2020. https://www.axios.com/states-face-coverings-mandatory-a0e2fe 35-5b7b-458e-9d28-3f6cdb1032fb.html.

Filindra, Alexandra, and Noah J. Kaplan. 2016. "Racial Resentment and Whites' Gun Policy Preferences in Contemporary America." Political Behavior 38:255-75.

Filosa, Gwen. 2017. "Gay-Basher Yelled 'You're in Trump Country Now' Offers to Hug His Victims.” Miami Herald, June 15. Retrieved August 27, 2020. https:/www.miamiherald.com/ news/local/community/florida-keys/article156277994.html.

Foley, Aris. 2020. "Calls to Poison Control Centers Spike after Trump Disinfectant Comments." The Hill, April 26. Retrieved August 27, 2020. https://thehill.com/policy/healthcare/494744poison-control-centers-report-increase-in-calls-pertaining-toexposure-to.

Forbes. 2020. \#18 Rush Limbaugh. Forbes. Retrieved August 27, 2020. https://www.forbes.com/profile/rushlimbaugh/\#79123a2669cc.

Fullman, Nancy, Bree Bang-Jensen, Kenya Amano, Christopher Adolph, and John Wilkerson. 2020. "State-Level Social Distancing Policies in Response to COVID-19 in the US." Version 1.16. Retrieved August 27, 2020. https:/github.com/ COVID19StatePolicy/SocialDistancing.
Gollwitzer, Anton, Cameron Martel, William J. Brady, Philip Pärnamets, Isaac G. Freedman, Eric D. Knowles, and Jay J. van Bavel. 2020. "Partisan Differences in Physical Distancing Predict Infections and Morality during the Coronavirus Pandemic." Unpublished paper, Department of Psychology, Yale University. Retrieved August 27, 2020. https://psyarxiv. com/t3yxa/.

Gottfredson, Michael R., and Travis Hirschi. 1990. A General Theory of Crime. Stanford, CA: Stanford University Press.

Graham, Amanda, Francis T. Cullen, Leah C. Butler, Teresa C. Kulig, Alexander L. Burton, and Velmer S. Burton, Jr. 2020. "Who Wears the MAGA Hat? White Nationalism and Faith in Trump" Working Paper, Georgia Southern University.

Graham, David A. 2019. “Trump's Unpardonable Admission about His Border Wall." The Atlantic, August 28. Retrieved August 27, 2020. https://www.theatlantic.com/ideas/archive/2019/08/ trump-pardons-border-wall/596962/.

Graham, Jesse, Jonathan Haidt, and Brian A. Nosek. 2009. "Liberals and Conservatives Rely on Different Sets of Moral Foundations." Journal of Personality and Social Psychology 96(5):1029-46.

Grasmick, Harold G., Charles R. Tittle, Robert J. Bursik, Jr., and Bruce J. Arneklev. 1993. "Testing the Core Empirical Implications of Gottfredson and Hirschi's General Theory of Crime." Journal of Research in Crime and Delinquency 30(1):5-29.

Haidt, Jonathan. 2012. The Righteous Mind: Why Good People Are Divided by Politics and Religion. New York: Vintage.

Haidt, Jonathan, and Jesse Graham. 2009. "Planet of the Durkheimians: Where Community, Authority, and Sacredness Are Foundations of Morality." Pp. 371-401 in Social and Psychological Bases of Ideology and System Justification, edited by J. T. Jost, A. C. Kay, and H. Thorisdottir. New York: Oxford University Press.

Haidt, Jonathan, Jesse Graham, and Craig Joseph. 2009. “Above and below Left-Right: Ideological Narratives and Moral Foundations." Psychological Inquiry 20(2-3):110-19.

Hains, Tim. 2019. "Trump Calls into 'Fox \& Friends' amid Impeachment Probe, Upcoming FISA Report." RealClear Politics, November 22. Retrieved August 27, 2020. https:// www.realclearpolitics.com/video/2019/11/22/trump_calls_in to_fox_friends_amid_impeachment_probe_upcoming_fisa report.html.

Hale, Henry E., and Olga Kamenchuk. 2020. "Why Are Republicans Using Putin's Talking Points? This Study Helps Explain.” The Washington Post, February 4. Retrieved August 27, 2020. https://www.washingtonpost.com/politics/2020/02/04/whyare-republicans-using-putins-talking-points-this-study-helpsexplain/.

Haner, Murat, Melissa M. Sloan, Justin T. Pickett, and Francis T. Cullen. 2020. "Safe Haven or Dangers Place? Stereotype Amplification and Americans' Perceived Risk of Terrorism, Violent Street Crime, and Mass Shootings.” British Journal of Criminology.

Harper, John. 2019. "Cleveland Man Threatens Black Neighbors with Slur, Says 'Donald Trump Will Fix Them,' Police Say.” Cleveland.com, January 11. Retrieved August 27, 2020. https://www.cleveland.com/court-justice/2016/06/cleveland man calls neighbors.html.

Hatemi, Peter K., Charles Crabtree, and Kevin B. Smith. 2019. "Ideology Justifies Morality: Political Beliefs Predict Moral 
Foundations." American Journal of Political Science 63(4):788806.

Hawdon, James E. 2001. "The Role of Presidential Rhetoric in the Creation of a Moral Panic: Reagan, Bush, and the War on Drugs." Deviant Behavior 22(5):419-45.

Herman, Shaina, and Greg Pogarsky. Forthcoming. "Morality, Deterrability, and Offender Decision Making." Justice Quarterly.

Hochschild, Arlie Russell. 2018. Strangers in Their Own Land: Anger and Mourning on the American Right. New York: New Press.

Hooghe, Marc, and Ruth Dassonneville. 2018. "Explaining the Trump Vote: The Effect of Racist Resentment and Antiimmigrant Sentiments." PS: Political Science \& Politics 51(3):528-34.

Jackson, David. 2019. “'Treason,' 'Spying,' 'Civil War': Donald Trump Lashes Out at Impeachment Accusers." USA Today, September 30. Retrieved August 27, 2020. https://www.usatoday.com/story/news/politics/2019/09/30/donald-trumpattacks-impeachment-accusers-tweets/3817248002/.

Jackson, Paul. 2019. "Donald Trump Is the Archetypal FarRight Charismatic Leader. But His Magic Won't Last." The Guardian, July 19. Retrieved August 27, 2020. https://www. theguardian.com/commentisfree/2019/jul/19/donald-trumparchetypal-far-right-charismatic-leader.

Janoff-Bulman, Ronnie, and Nate C. Carnes. 2013. "Surveying the Moral Landscape: Moral Motives and Group-Based Moralities." Personality and Social Psychology Review 17(3):219-36.

Jardina, Ashley E. 2019. White Identity Politics. New York: Cambridge University Press.

Johnson, Marty. 2020. "FBI May Charge Man Who Attacked Asian Americans over Coronavirus with Hate Crime: Report." The Hill, April 1. Retrieved August 27, 2020. https://thehill.com/ homenews/state-watch/490692-fbi-may-charge-man-whoattacked-asian-americans-over-coronavirus-with.

Kaufmann, Eric. 2018. Whiteshift: Populism, Immigration and the Future of White Majorities. New York: Abrams.

Khazan, Olga. 2016. "Why People Fall for Charismatic Leaders." The Atlantic, October 13. Retrieved August 27, 2020. https:// www.theatlantic.com/science/archive/2016/10/why-peoplefall-for-charismatic-leaders/503906/.

KOMO Staff. 2016. "African-American Man Stabbed in Olympia, Attacker Mentions Black Lives Matter.” Retrieved August 27, 2020. https://komonews.com/news/local/african-american-manstabbed-in-olympia-attacker-mentions-black-lives-matter.

Koop, Chacour. 2020. "Woman Licks Freezer Door Handle at Grocery to 'Protest' Coronavirus, Wisconsin Cops Say." Kansas City Star, March 20. Retrieved August 27, 2020. https:// www.kansascity.com/news/coronavirus/article241377711. html.

Kroneberg, Clemens, Isolde Heintze, and Guido Mehlkop. 2010. "The Interplay of Moral Norms and Instrumental Incentives in Crime Causation." Criminology 48(1):259-94.

Lawrence, Adam B. 2004. "Does It Matter What the Presidents Say? The Influence of Presidential Rhetoric on the Public Agenda, 1946-2003." Unpublished doctoral dissertation, University of Pittsburgh, Pittsburgh, PA.

LeBlanc, Paul. 2020. "Coronavirus: Texas Lt. Gov. under Fire for Comments.” Mercury News, March 24. Retrieved August 27,
2020. https://www.mercurynews.com/2020/03/24/coronavirus-texas-lt-gov-under-fire-for-comments/.

Leonhardt, David. 2020. “A Complete List of Trump's Attempts to Play Down Coronavirus." The New York Times, March 15. Retrieved August 27, 2020. https://www.nytimes. com/2020/03/15/opinion/trump-coronavirus.html.

Levensen, Eric, and Amanda Jackson. 2020. "Pool Party at Lake of the Ozarks in Missouri Draws a Packed Crowd." CNN, May 24. Retrieved August 27, 2020. https:/www.cnn.com/2020/05/24/ us/ozarks-missouri-party/index.html.

Levin, Bess. 2020. "GOP Congressman: Lawmakers Must 'Put on Our Big Boy and Big Girls Pants' and Let Americans Die.' Vanity Fair. Retrieved August 27, 2020. https://www.vanityfair. com/news/2020/04/trey-hollingsworth-coronavirus-economy.

Levin, Brian, and Lisa Nakashima. 2019. "Report to the Nation: 2019: Factbook on Hate \& Extremism in the U.S. \& Internationally." San Bernardino, CA: Center for the Study of Hate and Extremism.

Liptak, Kevin, and Jason Hoffman. 2020. "Trump Lashes Out in Grievance-Filled Briefing Claiming 'Total' Authority as President." CNN. Retrieved August 27, 2020. https://www. cnn.com/2020/04/13/politics/trump-coronavirus-defensefauci/index.html.

Lipton, Eric, David E. Sanger, Maggie Haberman, Michael D. Shear, Mark Mazzetti, and Julian E. Barnes. 2020. "He Could Have Seen What Was Coming: Behind Trump's Failure on the Virus." The New York Times, April 11. Retrieved August 27, 2020. https://www.nytimes.com/2020/04/11/us/politics/coronavirus-trump-response.html.

Lowry, Brian. 2017. "Donald Trump's Obsession with His Ratings, Even When He's Wrong, Is Nothing New." CNN, January 25. Retrieved August 27, 2020. https://money.cnn. com/2017/01/25/media/apprentice-ratings-obsession-donaldtrump/index.html.

Lurie, David R. 2020. "Republicans Cheer as Trumpist Judge Launches Holy War against Government." The Daily Beast. Retrieved August 27, 2020. https://www.thedailybeast.com/ republicans-cheer-as-trumpist-judge-justin-walker-launchesholy-war-against-government.

Malka, Ariel, Danny Osborne, Christopher J. Soto, Lara M. Greaves, Chris G. Sibley, and Yphtach Lelkes. 2016. "Binding Moral Foundations and the Narrowing Of Ideological Conflict to the Traditional Morality Domain." Personality and Social Psychology Bulletin 42(9):1243-57.

Maxwell, Angie, and Todd Shields. 2019. The Long Southern Strategy: How Chasing White Voters in the South Changed American Politics. New York: Oxford University Press.

McManus, Hannah D., Francis T. Cullen, Cheryl Lero Jonson, Alexander L. Burton, and Velmer S. Burton, Jr. 2019. "Will Black Lives Matter to the Police? African Americans' Concerns about Trump's Presidency." Victims \& Offenders 14(8):1040-62.

Mervosh, Sarah, Denise Lu, and Vanessa Swales. 2020. "See Which States and Cities Have Told Residents to Stay at Home." The New York Times, April 3. Retrieved August 27, 2020. https:// www.nytimes.com/interactive/2020/us/coronavirus-stay-athome-order.html.

Milesi, Patrizia, and Augusta Isabella Alberici. 2018. "Pluralistic Morality and Collective Action: The Role of Moral Foundations." Group Processes \& Intergroup Relations 21(2):235-256. 
Mosk, Matthew. 2020. "George W. Bush in 2005: 'If We Wait for a Pandemic to Appear, It Will Be Too Late to Prepare." ABC News, April 5. Retrieved August 27, 2020. https://abcnews. go.com/Politics/george-bush-2005-wait-pandemic-late-prepare/story? id $=69979013$.

Murdock, Jason. 2020. "U.S. Churches Hold Public Sunday Services Despite Coronavirus Outbreak: 'This Is Dangerous.” Newsweek, March 23. Retrieved August 27, 2020. https://www. newsweek.com/church-sunday-service-open-despite-coronavirus-covid19-health-advice-social-distancing-1493756.

Murphy, Sean. 2020. "Health Official: Trump Rally ‘Likely’ Source of Virus Surge.” Associated Press, July 8. Retrieved August 27, 2020. https://apnews.com/ad96548245e186382225818d$8 \mathrm{dc} 416 \mathrm{eb}$.

Nagin, Daniel S., and Greg Pogarsky. 2001. "Integrating Celerity, Impulsivity, and Extralegal Sanction Threats into a Model of Gender Deterrence: Theory and Evidence." Criminology 39(4):865-92.

The New York Times. 2020. "Coronavirus in the U.S.: Latest Map and Case Count." The New York Times, March 28. Retrieved August 27, 2020. https://www.nytimes.com/interactive/2020/ us/coronavirus-us-cases.html.

NPR/PBS NewsHour/Marist Poll. 2020. "Coronavirus.” Retrieved August 27, 2020. http://maristpoll.marist.edu/npr-pbs-newshour-marist-poll-results-coronavirus/\#sthash.Sx1nFrEP. PkA2FB82.dpbs.

Obama, Barack. 2014. "Obama Weekly Address on Ebola: 'We Can Beat This Disease." RealClear Politics, October 25. Retrieved August 27, 2020. https://www.realclearpolitics.com/ video/2014/10/25/obama_weekly_address_on_ebola_we can beat this_disease.html.

Ortiz, Jorge L. 2020. "Coronavirus in the US: How All 50 States Are Responding - and Why There Is No Federal Stay-at-Home Order." USA Today, March 30. Retrieved August 27, 2020. https://www.usatoday.com/story/news/nation/2020/03/30/ coronavirus-stay-home-shelter-in-place-orders-bystate/5092413002/.

Paternoster, Raymond. 2018. "Perceptual Deterrence Theory." Pp. 81-106 in Deterrence, Choice, and Crime: Contemporary Perspectives, edited by Daniel S. Nagin, Francis T. Cullen, and Cheryl Lero Jonson. New York: Routledge.

Paternoster, Ray, Chae Mamayek Jaynes, and Theodore Wilson. 2017. "Rational Choice Theory and Interest in the 'Fortune of Others." Journal of Research in Crime and Delinquency 54(6):847-68.

Paternoster, Raymond, and R. Bachman. 2013. "Perceptual Deterrence Theory." Pp. 649-71 in The Oxford Handbook of Criminological Theory, edited by Francis T. Cullen, and Pamela Wilcox. New York: Oxford University Press.

Paz, Christian. 2020. "All the President's Lies about the Coronavirus." The Atlantic, March 24. Retrieved August 27, 2020. https://www.theatlantic.com/politics/archive/2020/03/ trumps-lies-about-coronavirus/608647/.

Peel, Corley. 2020. "Police: Woman Coughed in Jacksonville Officer's Face, Told Him She Had Coronavirus." News4Jax, April 3. Retrieved August 27, 2020. https://www.news4jax. com/news/local/2020/04/03/police-woman-coughed-in-jacksonville-officers-face-told-him-she-had-coronavirus/.

Peer, Eyal, Joachim Vosgerau, and Alessandro Acquisti. 2014. "Reputation as a Sufficient Condition for Data Quality on
Amazon Mechanical Turk." Behavior Research Methods 46:1023-31.

Pei, Sen, Sasikiran Kandula, and Jeffrey Shaman. 2020. "Differential Effects of Intervention Timing on COVID-19 Spread in the United States." medRxiv. Retrieved August 27, 2020. https:// doi.org/10.1101/2020.05.15.20103655.

Pereira, Ana. 2017. "The Decision to Participate in Mediation and Individual Factors: The Role of Moral Foundations and Their Relation to Restorative and Retributive Orientations." Restorative Justice 5(2):221-50.

Pettus, Emily Wagster. 2020. "Governor: Mississippi Not 'Dictator' on Limits during Virus." The News \& Observer, March 25. Retrieved August 27, 2020. https://www.newsobserver.com/ news/article241495111.html.

Pew Research Center. 2018. "Trends in Party Affiliation among Demographic Groups.” Retrieved August 27, 2020. https:// www.people-press.org/2018/03/20/1-trends-in-party-affiliation-among-demographic-groups/.

Pew Research Center. 2020. "Worries about Coronavirus Surge, as Most Americans Expect a Recession-or Worse." Retrieved August 27, 2020. https://www.people-press.org/2020/03/26/ worries-about-coronavirus-surge-as-most-americans-expect-arecession-or-worse/.

Pickett, Justin T., Sean Patrick Roche, and Greg Pogarsky. 2018. "Toward a Bifurcated Theory of Emotional Deterrence." Criminology 56(1):27-58.

Pogarsky, Greg. 2004. "Projected Offending and Contemporaneous Rule-Violation: Implications for Heterotypic Continuity." Criminology 42(1):111-35.

Post, Jerrold M., and Stephanie R. Doucette. 2019. Dangerous Charisma: The Political Psychology of Donald Trump and His Followers. New York: Pegasus.

Pratt, Travis C., and Francis T. Cullen. 2000. "The Empirical Status of Gottfredson and Hirschi's General Theory of Crime: A Meta-Analysis." Criminology 38(3):931-64.

Qiu, Linda. 2020. “Analyzing the Patterns in Trump's Falsehoods about Coronavirus." The New York Times, March 27. Retrieved August 27, 2020. https://www.nytimes.com/2020/03/27/us/ politics/trump-coronavirus-factcheck.html.

Ramirez, Mark D. 2013. "Punitive Sentiment." Criminology 51():329-64.

Rising, David, and Geir Moulson. 2020. "Angela Merkel Rises to the Coronavirus Leadership Challenge." Christian Science Monitor, March 29. Retrieved August 27, 2020. https://www. csmonitor.com/World/Europe/2020/0329/Angela-Merkelrises-to-the-coronavirus-leadership-challenge.

Rodriguez, Adrianna. 2020. "Texas's Lieutenant Governor Suggests Grandparents Are Willing to Die for the US Economy." USA Today, March 24. Retrieved August 27, 2020. https://www. usatoday.com/story/news/nation/2020/03/24/covid-19-texasofficial-suggests-elderly-willing-die-economy/2905990001/.

Rubin, Jennifer. 2020. “Trump's Narcissism Has Never Been More Dangerous." The Washington Post, March 30. Retrieved August 27, 2020. https://www.washingtonpost.com/opinions/2020/03/30/trumps-narcissism-has-never-been-more-dangerous/.

Rucker, Philip, and Carol D. Leonnig. 2020. A Very Stable Genius: Donald J. Trump's Testing of America. New York: Penguin.

Rupar, Aaron. 2020a. "Trump's Friday Night Effort to Weaponized Coronavirus against His Enemies Has Already Aged Poorly." 
Vox, February 29. Retrieved August 27, 2020. https://www. vox.com/2020/2/29/21159294/trump-coronavirus-hoax-southcarolina-first-death.

Rupar, Aaron. 2020b. "Trump Spent Weeks Downplaying the Coronavirus. He's Now Pretending That Never Happened." Vox, March 18. Retrieved August 27, 2020. https://www.vox. com/2020/3/18/21184945/trump-coronavirus-comments-thenversus-now.

Santucci, Jeanine, John Fritze, and Courtney Subramanian. 2020. "Trump Extends Federal Social-Distancing Guidelines to April 30 after Floating Easter Deadline." USA Today, March 29. Retrieved August 27, 2020. https://www.usatoday.com/story/ news/politics/2020/03/29/coronavirus-trump-extends-socialdistancing-guidelines-april-30/2937504001/.

Schanzer, David. 2019. "We Must Call the El Paso Shooting What It Is: Trump-Inspired Terrorism." The Guardian, August 5. Retrieved August 27, 2020. https://www.theguardian.com/ commentisfree/2019/aug/05/trump-inspired-terrorism-el-paso.

Sharkey, Patrick. 2020. "The US Has a Collective Action Problem That's Larger Than the Coronavirus Crisis." Vox, April 10. Retrieved August 27, 2020. https://www.vox. com/2020/4/10/21216216/coronavirus-social-distancingtexas-unacast-climate-change.

Sharkey, Patrick, and George Wood. 2020. "The Causal Effect of Social Distancing on the Spread of SARS-CoV-2." Unpublished manuscript, Woodrow Wilson School of Public and International Affairs, Princeton University. Retrieved August 27, 2020. https://osf.io/preprints/socarxiv/hzj7a/.

Sherman, Lawrence W. 1993. "Defiance, Deterrence, and Irrelevance: A Theory of the Criminal Sanction." Journal of Research in Crime and Delinquency 30(4):445-73.

Shi, Luzi, Yunmei Lu, and Justin T. Pickett. 2020. "The Public Salience of Crime, 1960-2014: Age-Period-Cohort and TimeSeries Analyses." Criminology 58(3):568-93.

Silver, Eric, and Leslie Abell. 2016. "Beyond Harm and Fairness: A Study of Deviance and Morality." Deviant Behavior 37():496508.

Silver, Eric, and Jasmine R. Silver. Forthcoming. "Morality and Self-Control: The Role of Binding and Individualizing Moral Motives." Deviant Behavior.

Silver, Jasmine R. 2017. "Moral Foundations, Intuitions of Justice, and the Intricacies of Punitive Sentiment." Law \& Society Review 51(2):413-50.

Silver, Jasmine R., and Eric Silver. 2017. "Why Are Conservatives More Punitive Than Liberals? A Moral Foundations Approach." Law and Human Behavior 41(3):258-72.

Smith, Isaac H., Karl Aquino, Spassena Koleva, and Jesse Graham. 2014. "The Moral Ties That Bind . . Even to Out-Groups: The Interactive Effect of Moral Identity and the Binding Moral Foundations." Psychological Science 25(8):1554-62.

Sommer, Will, Erin Branco, and Sam Stein. 2020. "Trumpists Urging People to Leave Their Homes to Own the Libs." The Daily Beast. Retrieved August 27, 2020. https:/www.thedailybeast.com/trump-loyalists-and-allies-urge-defiance-of-coronavirus-safety-measures.

Stanley-Becker, Isaac, Toluse Olorunnip, and Seung Min Kim. 2020. "Trump Foments Resistance to Democratic-Imposed Shutdowns, but Some Republican Governors Are Also Wary of Moving Too Fast." The Washington Post, April 17. Retrieved August 27, 2020. https://www.washingtonpost.com/politics/ trump-foments-resistance-to-democratic-imposed-shutdownsbut-some-republican-governors-are-also-wary-of-moving-toofast $/ 2020 / 04 / 17 / 5595$ e5fa-80c2-11 ea-9040-68981f488eed story.html.

Steib, Matt. 2020. “Trump on GOP's $\$ 500$ Billion Slush Fund: 'I'll Be the Oversight." New York Magazine, March 23. Retrieved August 27, 2020. https://nymag.com/intelligencer/2020/03/ trump-on-usd500-billion-slush-fund-ill-be-the-oversight.html.

Strauss, Valerie. 2020. "Trump Tweets Schools Should Open 'ASAP' (after a Fox News Host Said the Same Thing Sunday Night). Here Are Some Responses." The Washington Post, May 25. Retrieved August 27, 2020. https://www. washingtonpost.com/education/2020/05/25/trump-tweetsschools-should-open-asap-after-fox-news-host-said-samething-sunday-night-here-are-some-responses/.

Sullivan, Kate, and Ryan Nobles. 2020. "North Carolina Governor: Trump Insisted on Full Convention with No Face Masks or Social Distancing." CNN, May 29. Retrieved August 27, 2020. https://www.cnn.com/2020/05/29/politics/north-carolina-governor-trump-convention-no-face-masks/index.html.

Sullivan, Margaret. 2020. "Surrounded by Experts, Trump Still Needed an Intervention by Tucker Carlson to Take Coronavirus Seriously." The Washington Post, March 18. Retrieved August 27, 2020. https://www.washingtonpost. com/lifestyle/media/surrounded-by-experts-trump-stillneeded-an-intervention-by-tucker-carlson-to-take-coronavirus-seriously/2020/03/18/3cf67cb0-6922-11ea-9923-57073adce27c_story.html.

Sun, Lena H., and Josh Dawsey. 2020. "White House and CDC Remove Coronavirus Warnings about Choirs in Faith Guidance." The Washington Post, May 28. Retrieved August 27, 2020. https://www.washingtonpost.com/health/ white-house-and-cdc-remove-coronavirus-warnings-aboutchoirs-in-faith-guidance/2020/05/28/5d9c526e-a117-11ea9590-1858a893bd59_story.html.

Süssenbach, Philipp, Jonas Rees, and Mario Gollwitzer. 2019. "When the Going Gets Tough, Individualizers Get Going: On the Relationship between Moral Foundations and Prosociality." Personality and Individual Differences 136:122-31.

Swaine, Jon, and Juweek Adolphe. 2019. "Violence in the Name of Trump." The Guardian, August 28. Retrieved August 27, 2020. https:/www.theguardian.com/us-news/ng-interactive/2019/ aug/28/in-the-name-of-trump-supporters-attacks-database.

Tavernise, Sabrina, and Richard A. Oppel, Jr. 2020. "Spit On, Yelled At, Attacked: Chinese-Americans Fear for Their Safety." The New York Times, March 24. Retrieved August 27, 2020. https://www.nytimes.com/2020/03/23/us/chinesecoronavirus-racist-attacks.html.

Taylor, Derrick Bryson. 2020. "A Timeline of the Coronavirus Pandemic." The New York Times, July 21. Retrieved August 27, 2020. https://www.nytimes.com/article/coronavirus-timeline.html.

Tittle, Charles R. 1995. Control Balance: Toward a General Theory of Deviance. Boulder, CO: Westview.

Trump, Donald John. 2020a. "Donald J. Trump" [Twitter profile]. Retrieved August 27, 2020. https://witter.com/realDonaldTrump.

Trump, Donald J. 2020b. "Gallup Poll numbers on the handling of this situation are outstanding, the best. Thank you!" [Tweet]. 
Retrieved August 27, 2020. https://twitter.com/realDonaldTrump/status/1234305307439923201.

Trump, Donald J. 2020c. "President Trump is a ratings hit. Since reviving the daily White House briefing Mr. Trump and his coronavirus updates have attracted an average audience of 8.5 million on cable news, roughly the viewership of the season finale of 'The Bachelor.' Numbers are continuing to rise . .." [Tweet]. Retrieved August 27, 2020. https://twitter.com/realDonaldTrump/status/1244320570315018240.

Trump, Donald J. 2020d. "WE CANNOT LET THE CURE BE WORSE THAN THE PROBLEM ITSELF. AT THE END OF THE 15 DAY PERIOD, WE WILL MAKE A DECISION AS TO WHICH WAY WE WANT TO GO!" [Tweet]. Retrieved August 27, 2020. https://twitter.com/realDonaldTrump/status/1241935285916782593.

Trump Twitter Archive. 2020. “Trump Twitter Archive.” Retrieved August 27, 2020. http://www.trumptwitterarchive.com.

Trumpka, Richard. 2020. "Trump's Dangerous Decision on Meatpacking Plants." The New York Times, May 7. Retrieved August 27, 2020. https://www.nytimes.com/2020/05/07/opinion/trump-meat-plants-coronavirus.html.

Tulis, Jeffrey K. 1987. The Rhetorical Presidency. Princeton, NJ: Princeton University Press.

van Gelder, Jean-Louis, and Reinout E. de Vries. 2012. "Traits and States: Integrating Personality and Affect into a Model of Criminal Decision Making." Criminology 50(3):637-71.

van Leeuwen, Florian, and Justin H. Park. 2009. "Perceptions of Social Dangers, Moral Foundations, and Political Orientation." Personality and Individual Differences 47(3):169-73.

van Leeuwen, Florian, Justin H. Park, Bryan L. Koenig, and Jesse Graham. 2012. "Regional Variation in Pathogen Prevalence Predicts Endorsement of Group-Focused Moral Concerns." Evolution and Human Behavior 33(5):429-37.

Vaughan, Tyler J., Lisa Bell Holleran, and Jasmine R. Silver. 2019. "Applying Moral Foundations Theory to the Explanation of Capital Jurors' Sentencing Decisions." Justice Quarterly 36(7):1176-1205.

Vazquez, Maegan, and Betsy Klein. 2020. “Trump Again Defends Use of the Term "China Virus." CNN Politics, March 19. Retrieved August 27, 2020. https://www.cnn.com/2020/03/17/ politics/trump-china-coronavirus/index.html.

Vazsonyi, Alexander T., Jakub Mikuška, and Erin L. Kelley. 2017. "It's Time: A Meta-Analysis on the Self-Control-Deviance Link." Journal of Criminal Justice 48(1):48-63.

Visser, Nick. 2020. "Trump Defends His Weeks Downplaying Coronavirus: I'm a Cheerleader." HuffPost, April 7. Retrieved August 27, 2020. https://www.huffpost.com/entry/trump-coronavirus-cheerleader_n_5e8d0872c5b6e1a2e0fb7aeb?ncid=AP PLENEWS00001.

Warr, Mark, and Christopher G. Ellison. 2000. "Rethinking Social Reactions to Crime: Personal and Altruistic Fear in Family Households." American Journal of Sociology 106(3):551-78.

Weinberg, Jill D., Jeremy Freese, and David McElhattan. 2014. "Comparing Data Characteristics and Results of an Online Factorial Survey between a Population-Based and a Crowdsource-Recruited Sample." Sociological Science 1(19):292-310.

Williamson, Elizabeth. 2020. "Liberty University Brings Back Its Students, and Coronavirus Fears, Too." The New York Times,
March 29. Retrieved August 27, 2020. https://www.nytimes. com/2020/03/29/us/politics/coronavirus-liberty-universityfalwell.html.

Winton, Richard, and Hannah Fry. 2020. "Coronavirus Scofflaws Arrested, Criminally Charged as California Cracks Down." The Los Angeles Times, April 4. Retrieved August 27, 2020. https://www.latimes.com/california/story/2020-04-04/coronavirus-violators-arrested-criminally-charged-california-cracksdown.

Wolsko, Christopher, Hector Ariceaga, and Jesse Seiden. 2016. "Red, White, and Blue Enough to Be Green: Effects of Moral Framing on Climate Change Attitudes and Conservatism." Journal of Experimental Social Psychology 65:7-19.

Wulfsohn, Joseph A. 2020. "Fox News Reaches Highest Viewership in Network's History, Topping MSNBC, CNN in 2020." Fox News, February 25. Retrieved August 27, 2020. https://www. foxnews.com/media/highest-viewership-network-historymsnbc-cnn-2020.

Yahoo News/YouGov. 2020. "Yahoo News/YouGov: Most Americans Are Worried about COVID-19-but Not Republicans." Retrieved August 27, 2020. https://today.yougov.com/topics/health/articles-reports/2020/03/12/coronavirus-data-poll.

Yong, Ed. 2020. "How the Pandemic Defeated America: A Virus Has Brought the World's Most Powerful Country to Its Knees." The Atlantic, September. Retrieved August 27, 2020. https:// www.theatlantic.com/magazine/archive/2020/09/coronavirusamerican-failure/614191/.

Zhao, Christina. 2020. “After Trump's Disinfectant Comments, Calls to Poison Control Centers Spike in New York, Michigan, Illinois and Maryland." Newsweek, April 26. Retrieved August 27, 2020. https://www.newsweek.com/after-trumps-disinfectant-comments-calls-poison-control-centers-spike-new-yorkmichigan-1500294.

\section{Author Biographies}

Amanda Graham is an assistant professor in the Department of Criminal Justice and Criminology at Georgia Southern University. She is a recent graduate from the School of Criminal Justice at the University of Cincinnati, where she has worked in the International Association of Chiefs of Police/University of Cincinnati Center for Police Research and Policy. Her current research interests focus on policing, police-community relations, the public perceptions of and reactions to COVID-19, public opinion, scale development, and measurement.

Francis T. Cullen is distinguished research professor emeritus and a senior research associate in the School of Criminal Justice at the University of Cincinnati. He is a past president of the American Society of Criminology and the Academy of Criminal Justice Sciences. He is a coauthor of Confronting School Violence: A Synthesis of Six Decades of Research (Cambridge University Press). His current interests include developing the rehabilitationredemption model of corrections and the criminology of Donald Trump.

Justin T. Pickett is an associate professor in the School of Criminal Justice at the State University of New York at Albany. He is the 2015 recipient of the American Society of Criminology's Ruth 
Shonle Cavan Young Scholar Award. His research interests include survey research methods, public opinion, police-community relations, and theories of punishment.

Cheryl Lero Jonson is an associate professor in the Department of Criminal Justice at Xavier University in Cincinnati. She is coauthor of Correctional Theory: Context and Consequences and of Deterrence, Choice, and Crime: Contemporary Perspectives. Her current research interests focus on the impact of prison on recidivism, public opinion and criminal justice policy, civilian active assailant responses, and the public's response to the COVID-19 pandemic.
Murat Haner is an instructor in the Department of Criminology at the University of South Florida. He is author of The Freedom Fighter: A Terrorist's Own Story. His current research focuses on public opinion on policy issues, including gun control, police use of force, and terrorism.

Melissa M. Sloan is an associate professor of sociology and interdisciplinary social sciences at the University of South Florida. Her research interests include the sociology of emotion, with a particular focus on fear of terrorism and psychological well-being, and the interdisciplinary research process. 